Revista lus et Praxis, Año 18, No 2, 2012, pp. 243 - 294

ISSN 0717 - 2877

Universidad de Talca - Facultad de Ciencias Jurídicas y Sociales

Prudencia versus Ideología:

"De nuevo sobre el papel del juez en el proceso civil"

Andrés de la Oliva Santos

\title{
PRUDENCIA VERSUS IDEOLOGÍA: DE NUEVO SOBRE EL PAPEL DEL JUEZ EN EL PROCESO CIVIL*
}

\author{
Andrés de la Oliva Santos**
}

\section{CONSIDERACIÓN PRELIMINAR}

Cumplidos holgadamente cuarenta años desde mi primera publicación sobre asuntos procesales, me he ocupado en muchas ocasiones de lo que, a mi entender, le corresponde al juez en los procesos civiles en que se ventilan derechos e intereses legítimos de sujetos jurídicos particulares sin presencia de un interés público prevalente.

Estas páginas, como sus predecesoras de 2010¹, pertenecen al género del ensayo. Y el ensayo, como dijo Ortega y GASSET, es "la ciencia sin la prueba explícita"2. Sé que sobre el ensayo se han emitido, con sarcasmo, juicios peyorativos e incluso ácidos ${ }^{3}$. Pero Ortega no lo definía con los términos transcritos

\footnotetext{
* Colaboración recibida el 30 de septiembre y aprobada el 22 de octubre de 2012.

${ }_{* *}^{*}$ Catedrático de Derecho Procesal Universidad Complutense de Madrid. Correo electrónico: andresoliva@infonegocio.com.

${ }^{1}$ Predecesoras son las páginas tituladas "El papel y los poderes del Juez en el Proceso Civil", publicadas en Teoría \& Derecho. Revista de Pensamiento Jurídico, Valencia, junio 7/2010, pp. 36-66. Redacté ese texto a petición del Prof. Montero Aroca, que planeaba un número monográfico de la citada revista con exposiciones contrapuestas del tema. Es decir: unos textos en defensa de un juez civil con grandes poderes y otros, en cambio, preconizadores de un juez civil neutral (o "pasivo") y notablemente circunscrito por los planteamientos de las partes, tanto respecto del objeto del proceso y de una estricta congruencia de la sentencia, como en lo relativo a la formación del juicio sobre los hechos relevantes de cada litigio civil (admisión de hechos, prueba, etc.). Cuando mi querido amigo el Prof. Dr. Diego I. Palomo Vélez, me pide permiso para reproducir en lus et Praxis, que tan acertadamente dirige, lo publicado en Teoría y Derecho, le propongo revisar, reescribir y ampliar ese texto, por parecerme más conforme al gran prestigio alcanzado por la publicación chilena, a mi condición de miembro de su Comité editorial y a mi deseo de procurar un texto con la máxima "frescura", aunque sin hurtar al lector nada de lo que escribí en 2010. Aceptada de inmediato mi propuesta, el resultado es este trabajo, al que, con buenas razones, he puesto un título nuevo, en el que aparecen dos ingredientes: el de la ideología, por el que, muy a mi pesar, se mantiene viva la ya injustificadamente prolongada vexata quaestio de los poderes del juez civil, y el de la prudencia, con el que pienso que el habitual planteamiento ideologizado debiera superarse.

${ }^{2}$ En Meditaciones del Quijote, 1914, ed. Aguilar (reimp.) Madrid, 1975, p. 36.

${ }^{3}$ Por ejemplo, el de que un ensayo es un conjunto de ocurrencias sin notas a pie de página. Error, pues con esta nota, por ejemplo, no desaparece el carácter ensayístico de este papel. Me permito advertir
} 
para descalificarlo sino, muy al contrario, por considerarlo legítimo y para que esa legitimidad quedara establecida. Pues bien: aplicado el criterio orteguiano a un trabajo sobre asunto jurídico, significa, entre otras cosas, que la extensión puede y suele ser moderada; que el autor está liberado de sujeciones formales; que es de esperar, mucho más que la exposición sistemática completa y erudita, la reflexión y la posición personal y, finalmente, que el discurso se impregna de una especial intensidad retórica o persuasiva.

Esto último conviene mucho a la realidad de una cuestión controvertida y también a la intención de alimentar polémica con que inicialmente se me pidió que tratara la cuestión. Otra cosa, como se verá, es que lo que diga a partir de ahora responda a las expectativas de quienes esperen o incluso deseen encontrarse en estas páginas la defensa cerrada de una de las posiciones de la controversia, en el habitual marco de una discusión con un claro trasfondo ideológico-político. Eso no lo encontrarán aquí. Me opondré, es verdad, a la idea de un papel que al Juez le debería corresponder en el proceso civil, pero esta oposición a un papel pretendidamente obligado del juez no será sino la oposición a cualquier dogmatismo sobre el "rol" del juez y, por supuesto, a la pretensión de imponer universalmente tal dogmatismo. En 2010 aventuré que el ingrediente picante de la polémica dependería de lo que otros afirmasen más que de lo que yo dijera. Y también deseé que, por la inteligencia de los demás polemizadores, el resultado fuesen muchas más convergencias de las habituales hace años. Los resultados, en efecto, fueron positivos. Pero deseo que el progreso sea mayor y lamento algún concreto retroceso, alguna renovada insistencia en tratar nuestro tema con el acostumbrado arsenal del axioma ideológico-político ${ }^{4}$.

\section{El PAPEl del JueZ en el PROCESO CIVIL y lOS PRINCIPIOS DEL PROCESO}

Por la intensidad y la duración de la polémica sobre el papel del juez, cabría pensar que están en juego "cuestiones de principios", es decir, grandes valores

que aquí las notas a pie de página (a excepción de las relativas a citas) no tienen menos interés que el texto principal, sino que, por el contrario, resultan de recomendable lectura para entenderlo.

${ }^{4}$ Me estoy refiriendo a TARUFFO y a sus afirmaciones en una reciente entrevista realizada y publicada en España: Diario La Ley, No 7887, Sección "En Primera Persona", 25.06.2012, Año XXXII. Dejo aquí el enlace para que los lectores puedan acceder a la entrevista entera, con diversos contenidos de los que me ocuparé después: http://diariolaley.laley.es/Content/Documento.aspx?params=H4sIAAAAAAAEAO 29B2AcSZYlJi9tynt/SvVK1+B0oQiAYBMk2JBAEOzBiM3mkuwdaUcjKasqgcplVmVdZhZAzO2dvPfee+ +999577733ujudTif33/8/XGZkAWz2zkrayZ4hgKrlHz9+fB8/lorZ7LMXpzv07O7e33n48Bde5nVTVMv P9nZ293bu39vFB8X59dNq+uZ6IX92npVN/guL5ni1qqvLfCbtPt17sHtvd+//AZmgGw9NAAAAWKE. Sé que la amistad no impide a TARUFFO la discrepancia, lo que me parece perfecto, porque soy del mismo criterio. Deseo y espero que mi desacuerdo en estas páginas no altere nuestra muy buena relación personal y profesional, que ha tenido tantas fructíferas manifestaciones. 
humanos con dimensiones de justicia y orden o, lo que es igual, grandes valores jurídicos (lo que, en España, desde la Constitución de 1978, se designa con la expresión "valores superiores" del ordenamiento jurídico). Como se verá, no me parece que sea así tratándose de la generalidad de los procesos civiles, pero no está de más exponer algunas ideas sobre los principios del proceso, sentado que lo concibo como un instrumento ineludible de la Jurisdicción, cuya finalidad esencial no es resolver controversias o conflictos, sino decir el Derecho ante casos concretos, pequeños trozos de historia humana.

Como ya he escrito en otros lugares, considero principios del proceso o principios procesales las ideas y reglas que constituyen puntos de partida para la construcción de los instrumentos esenciales de la función jurisdiccional, en el muy preciso sentido de poseer una virtualidad originaria (de ahí que el término "principio" resulte apropiado), determinando que los procesos sean sustancialmente como son. No merecen, por tanto, el nombre de principios del proceso cualesquiera criterios inspiradores de la respuesta a las muy diversas cuestiones que se suscitan a la hora de establecer ciertas series o sucesiones de actos o su forma externa, sino sólo las ideas-fuerza o criterios determinantes de las principales opciones configuradoras de la sustancia interna de los procesos.

Desde varios puntos de vista, es erróneo y perturbador denominar "principios" a todos los criterios generales en virtud de los cuales se opta por regular de un modo o de otro el proceso o ciertos aspectos o actuaciones de éste. Para la mayoría de esos criterios resulta preferible utilizar los conceptos y términos de "reglas" o "máximas". Como he repetido en muchas ocasiones, cuando todo son principios, nada es principio. Y lo mismo sucede -y con impaciencia lo repito también una y otra vez- cuando a cualquier posibilidad de actuación humana se le denomina "derecho": cuando todo son "derechos", nada es derecho. Semejante amplitud conceptual no conduce a nada positivo ${ }^{5}$.

\footnotetext{
${ }^{5}$ Muy al contrario. Sin embargo, se ha convertido en una auténtica moda, de sesgo vulgar y retardatario, la de producir etiquetas y banderas máximamente genéricas y proceder, con tan menguado amparo, a eliminar distinciones de suma relevancia. La moda y sus efectos encuentran su origen en la ignorancia y la incultura y rinden homenaje a la pereza. Veamos un ejemplo. Lo que antes eran estudios de Periodismo (concepto que, por supuesto, no es incompatible con las innovaciones técnicas de los dos últimos siglos), ahora es "Ciencia de Comunicación", de modo tal que el foniatra y hasta el otorrinolaringólogo se hermanarían con quien explica Lengua española y con el experto en el manejo y coordinación de cámaras televisivas. Además -lo digo con el máximo respeto a las personas-, se funda un "Derecho a la información", que, con tamaña amplitud, englobaría por igual el de los televidentes que el de los accionistas de una sociedad mercantil o el de los ciudadanos respecto del contenido de los archivos y documentos oficiales o el de la parte pasiva de un proceso penal sobre la marcha de la instrucción. Empecé a reparar en este fenómeno hace muchos años, cuando leía como gran mérito de las teorías abstractas de la acción la aplicabilidad de ese concepto lo mismo al proceso civil que al penal. A nadie serio, defensor de las tesis abstractas, se le había ocurrido semejante simpleza. Pero, claro es, eso permitía no preguntarse por qué y sobre qué polemizaron WiNDSCHEID y MUTHER (y ni siquiera quiénes eran).
} 
Pero mi preocupación por los conceptos de "principio" y de "derecho" (subjetivo) no es sólo un cierto celo por la precisión o exactitud, de modo que los términos y conceptos se ajusten máximamente a la riqueza de la realidad. El deseo de que perduren y se aprovechen las conquistas de la ciencia y de la técnica-también, por tanto, de la ciencia y de la técnica jurídicas- sin retornar a nociones vulgares después de muchos razonables esfuerzos de precisión, obedece al propósito de no provocar equiparaciones que degradan los genuinos principios y los auténticos derechos. Principio es lo que constituye un origen y determina las diferencias esenciales. Si denominamos "principio" a todo criterio general, se pondrán a la par lo principal y lo accesorio. Y no parece razonable, por ejemplo, equiparar el principio de audiencia o el de igualdad con el denominado "principio" de economía procesal.

Los genuinos principios (los del proceso como los relativos a otras realidades) presentan, en sentido etimológico, un carácter radical (del latín radex-icis: raíz) por su relación íntima con dos necesidades primarias. En primer lugar, la de superar de verdad una situación de autotutela o "justicia privada", para lo que ha de darse satisfacción a unos pocos criterios que concretan aspiraciones de justicia universalmente sentidas. En segundo lugar, la de ajustar máximamente el instrumento procesal a la finalidad de tutelar eficazmente los diversos tipos de derechos subjetivos y las muy diferentes parcelas del Derecho objetivo.

En virtud de la primera necesidad, el proceso se ha de configurar de modo que siempre sean efectivos unos determinados postulados elementales de justicia: éstos son los principios procesales que he Ilamado "jurídico-naturales", siguiendo a mi maestro, CARRERAS Llansana. A causa de la segunda necesidad, en cambio, los procesos se construyen conforme a criterios contingentes: los que se consideran más adecuados según la diversa realidad jurídica de la que han de ser instrumentales. Se trata, por tanto, de principios procesales que no configuran siempre toda clase de procesos, sino que inspiran, unos, ciertas construcciones procesales, y otros, otras. Son los que algunos hemos dado en Ilamar "principios jurídico-técnicos".

En cuanto al primer tipo de principios procesales, los necesarios o "jurídiconaturales", he venido reduciéndolos a dos: el principio de audiencia (muy

Esto de la bondad generalizadora, como se me ocurre denominar al fenómeno, es, si bien se mira, algo peregrino (adjetivo que, no sé por qué, usamos en España para referirnos a lo absurdo). Por supuesto, el concepto de "asiento" es más comprensivo que el de "sillón", pero éste último define mejor que el de "asiento" un concreto instrumento para sentarse (el "sillón" tiene respaldo y brazos, elementos de que carece un "taburete", que, sin embargo, es, como el sillón, un "asiento"). A estos generalizadores, a los que también les resulta cómodo, por ejemplo, atribuir eficacia de cosa juzgada a todo y a sólo lo juzgado en resolución firme, me entran ganas de llamarles "entes". No lo hago, pero lo tendrían merecido conforme a sus tesis. ¿Se enterarán alguna vez de que conocer es distinguir, incluso para el conocimiento sensorial de un pez? 
resumidamente: nemo debetur inaudito damnari; audiatur et altera pars) y el principio de igualdad de las partes ${ }^{6}$. No son los principios de esta clase, insoslayables en todos los procesos (con aparentes excepciones), los que más influyen en el papel del juez en el proceso civil. Lo que al juez corresponde, o no, se relaciona estrechamente con el entendimiento de los principios denominados "jurídico-técnicos", que, a mi entender, no son sino el denominado "principio dispositivo" y, en contraposición, el "principio de oficialidad".

Tan corto número de genuinos principios procesales, así como su denominación -que, aunque no original, puede suscitar alguna extrañeza-, obedece, ante todo, a una opción expositiva o didáctica, que se sustenta en la argumentación que enseguida se verá exenta de pretensiones excluyentes de otros puntos de vista. También podrá advertirse, espero, que no hay una base ideológica concreta en mi modo de ver y exponer algunas claves del proceso civil. Pero, además, reservar el concepto de "principios del proceso" para unos pocos criterios, responde a una distinción, tempranamente aprendida de Carreras llansana, entre principios y formas del proceso, distinción en virtud de la cual una serie de importantes y muy visibles rasgos externos del proceso dependen, no tanto de criterios con virtualidad originaria y determinante de las principales características esenciales del proceso, como son los principios, sino de la opción por modelos de configuración externa del proceso, que serían las formas: inquisitiva o contradictoria. Desde hace años y hasta ahora, sigo en este punto (como en otros) las enseñanzas de mi maestro sobre los principios y las formas del proceso, respectivamente ${ }^{7}$. Un fundamento elemental pero sólido para la distinción entre principios y formas reside en la inexistencia de completa correlación entre unos y otras, puesto que la forma o estructura contradictoria puede coexistir con la influencia del principio dispositivo lo mismo que con la del principio de oficialidad.

Son, empero, genuinos principios procesales, "jurídico-técnicos", las ideas o criterios determinantes de la posición y del papel del tribunal y de las partes

\footnotetext{
${ }^{6}$ V. al respecto mi Derecho Procesal. Introducción, con Díez-Picazo Giménez, I. y Vegas Torres, J., Madrid, 2004, §3, núms. 5-18.

7 Esas enseñanzas de CARReras Llansana son, en España, propias de él únicamente, aunque podían encontrarse, con una formulación distinta, en Gómez OrbanejA, Derecho Procesal Civil (con Herce Quemada), Vol. I, Madrid, 1969, pp. 190 y ss. Sin duda, Gómez Orbaneja había recibido a Chiovenda, pero expresamente menciona como inspiración directa la clásica obra de MILLAR, R. W., The Formative Principles of Civil Procedure, Northwestern University Press, 1923, 78 pp. (existe trad. esp. por Grossmann, Buenos Aires, 1945, con el título "Los principios formativos del procedimiento civil"). Hay autores de mucha relevancia, en la doctrina alemana, que, en cierto modo, apuntan en la misma dirección cuando separan la Verhandlungsmaxime -concepto en sí mismo oscurísimo- del Dispositionsprinzip y del Officialprinzip. En cuanto a las formas procesales y su relación con los principios, v. mi Derecho Procesal. Introducción, cit. §4, passim.
} 
-con sus correspondientes funciones, facultades, derechos, deberes y cargas-, así como de las bases estructurales y de desarrollo y desenlace de los procesos. Son principios de ese tipo los que inspiran la capacidad de decisión y de influencia del órgano jurisdiccional y de las partes en el nacimiento del proceso, en su objeto, en su desenvolvimiento y en su terminación.

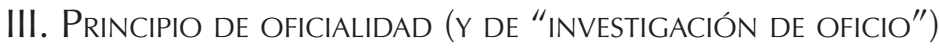 Y PRINCIPIO DISPOSITIVO (Y "DE APORTACIÓN DE PARTE")}

Dejo a un lado intencionadamente exponer, incluso en resumen, las innumerables discrepancias que entre los autores existen, desde el nacimiento del llamado "Derecho Procesal moderno", en torno a las denominaciones más apropiadas de los principios jurídico-técnicos que configuran los procesos. Pero voy a permitirme un breve recordatorio de conceptos conocidos, que considero imprescindible para que el lector pueda entender cabalmente mi posición. Y comenzaré por el principio de oficialidad, siguiendo un orden inverso al más frecuente. Recomiendo al lector que no se fije en las denominaciones (discutibles, como ya he dicho, pero sobre las que siempre cabría encontrar equivalencias suficientes), sino en la sustancia de lo que considero principios procesales.

\section{A) Principio de oficialidad (y "principio de investigación de oficio")}

Entiendo por principio de oficialidad el criterio, derivado del intenso interés público predominante en ciertas materias, en virtud del cual la Justicia se debe ocupar de los asuntos en que esté presente aquel interés, de modo que el proceso, su objeto, los actos procesales y la sentencia dependan de la promoción, defensa y tutela de ese interés público, con un protagonismo decisivo de órganos oficiales y del mismo órgano jurisdiccional. Tan pronto como un asunto que implique ese tan repetido interés (también conocido clásicamente como bonus communis, el "bien común") sea conocido, habrá de hacerse valer, sin que las partes procesales gocen, ni extraprocesal ni procesalmente, de un poder de disposición como el que cabe predicar respecto de los derechos e intereses legítimos de los que son titulares los sujetos jurídicos particulares.

Se comprende que una primera manifestación del principio de oficialidad es la necesidad de que el proceso comience siempre que aparezca el interés público de cuya satisfacción es instrumento el proceso. El inicio de éste no puede depender de la voluntad libre de un sujeto jurídico particular (no se inicia "a instancia de parte"), sino que se encomienda a la decisión reglada del mismo órgano jurisdiccional (comienza el proceso ex officio) o se impone la realización de actos de iniciativa a un órgano público, legalmente encargado, como se acaba de decir, de hacer valer el interés público general (en España y en otros muchos países suele ser el Ministerio Fiscal o Ministerio Público). 
En los procesos regidos por el principio de oficialidad, ni las partes son dueñas de establecer el objeto del proceso ni pueden disponer de éste libremente mediante el desistimiento (como máximo podrán algunas partes dejar de ser tales), ni cabe que la parte activa renuncie o que la pasiva se allane, o que ambas transijan, con los efectos propios de tales actos de disposición.

Por otro lado, aunque pueda confiarse en la iniciativa de los sujetos procesales en cuanto a la aportación de los hechos y a la proposición de las pruebas, el órgano jurisdiccional no se encuentra vinculado a tal iniciativa, sino que resulta razonable establecer que sea él quien la tome (investigación de oficio) o, al menos, que pueda (o más bien deba) acordar de oficio actuaciones probatorias. Tampoco hay vinculación del órgano jurisdiccional respecto del planteamiento jurídico que las partes puedan hacer, puesto que, dada la raíz del principio de oficialidad, la tutela del interés público no se debe subordinar a aquel planteamiento, que no enlaza con un poder de disposición particular que, o no existe siquiera, o no merece ser absolutamente respetado.

Finalmente, la actividad procesal y la resolución que ponga término al proceso estarán delimitadas, no tanto por las pretensiones de las partes (y, más precisamente, por los fundamentos fácticos y jurídicos de dichas pretensiones), como por una pequeña historia, una porción de realidad con dimensiones jurídicas, que ha dado origen y sentido al proceso. Las pretensiones (noción aquí utilizada literalmente, como acción y efecto de pretender) no serán del todo irrelevantes, desde luego, pero su relevancia guardará relación con la necesidad de preservar los principios de audiencia e igualdad, dentro de la forma contradictoria del proceso, esto es, en coherencia con una estructura procesal dual y de controversia.

Así, pues, las pretensiones de las partes, con sus fundamentos fácticos y jurídicos, no entrañarán, en un proceso regido por el principio de oficialidad, limitaciones del tribunal fundadas en el respeto a unos inexistentes (o subordinados) derechos e intereses legítimos de sujetos jurídicos particulares: habrán de tomarse en consideración sólo en la medida en que la satisfacción del interés público se ha de conseguir respetando el papel procesal atribuido a las partes, que, por la naturaleza de las cosas, es razonable configurar de modo que no se alce nunca como obstáculo para la satisfacción del fin del proceso, que es, insistimos, proteger un interés público. El principio de oficialidad y el de investigación de oficio inspiran la inmensa mayoría de los procesos penales, aunque también algunos procesos civiles, de los que resultan paradigmáticos los procesos de incapacitación y de reintegración de la capacidad. Ni que decir tiene que un proceso regido por el principio de oficialidad comporta la atribución al juez de numerosos e importantes poderes en los ámbitos ya apuntados ${ }^{8}$.

\footnotetext{
${ }^{8}$ He escrito este subepígrafe en esos concretos términos perfectamente a sabiendas de que, por incon-
} gruencias gigantescas, muy propias de los tiempos de incoherencia sincretista que vivimos, el proceso 


\section{B) Principio dispositivo (y "principio de aportación de parte")}

A mi entender, cabe definir el principio dispositivo como el criterio, derivado de la naturaleza eminentemente particular de los derechos e intereses en juego, en virtud del cual el proceso se construye asignando o reconociendo a las partes un papel de gran relieve, de modo que, en primer lugar, se hace depender la existencia real del proceso y su objeto concreto del libre poder de disposición de los sujetos jurídicos implicados en la tutela jurisdiccional, que al menos uno de ellos ha de pretender y, en segundo lugar, los resultados del proceso dependen en gran medida del ejercicio por las partes de las oportunidades de actuación procesal (alegaciones y prueba) abstractamente previstas en la norma jurídica.

Desde todo punto de vista, la manifestación primera del principio dispositivo es que el proceso no comience por iniciativa del propio órgano jurisdiccional (ne procedat iudex ex officio: "que el juez no proceda de oficio"), sino sólo por la de un sujeto jurídico que pretende obtener una tutela jurisdiccional concreta mediante la correspondiente resolución judicial. Nemo iudex sine actore, reza

penal resulta ser un proceso con un juez decisorio (sobre la fase de instrucción están las espadas en alto) pasivo y sin poderes, porque ese proceso ha sido pragmatizado hasta extremos difícilmente justificables si nos importa -y a mí me importan mucho- la verdad y la justicia y, a la vez, se ha dogmatizado según pretendidos "principios" jurídicos vaporosos, como sucede, en España, con un recreado e hiperampliado "principio acusatorio".

Este "principio" no consiste en que no se pueda condenar penalmente sin acusación ni en que todo encartado como parte pasiva de una causa criminal (llámesele sospechoso, imputado o acusado) tenga derecho, desde el principio de su implicación, a ser informado de los hechos que motivan cualquier resolución que limite sus derechos y, a fortiori, tenga derecho a saber de qué se le acusa (y quién) desde que haya acusación. No se trata de estas elementalidades, recogidas en nuestra Constitución. En España, el "principio acusatorio", que no estaba definido por la doctrina ni por la jurisprudencia (ni con amplio consenso ni sin él) y que no es mencionado de ninguna forma en la Constitución española, se ha hecho consistir, en síntesis, en que el juez penal está atado de pies y manos por la acusación, no sólo (como es razonable y equitativo) en cuanto a los hechos una vez que el objeto del proceso ha sido fijado, sino también en cuanto al Derecho.

Según este "principio", el tribunal penal no puede acordar pruebas de oficio ni promover debate entre las partes sobre cuestiones jurídicas a fin de dictar sentencia aplicando las normas penales con la soberanía que es coherente con el interés público en la represión jurídica de la delincuencia, pero sin indefensión de nadie. La congruencia de la sentencia penal con la acusación habría de ser tan absoluta o más que en un proceso civil sobre asuntos desprovistos de interés público. La neutralidad del juzgador penal sería la plena pasividad de un mero espectador. Todo esto, en nombre del "principio acusatorio" pretendidamente constitucional, contra numerosos preceptos legales vigentes.

Curioso es que, en buena medida, los que piden aumento de poderes para el juez civil sean, con frecuencia, ardientes defensores de este juez penal impasible. Diríase que para éstos reviste mayor interés social el cumplimiento de lo pactado en un contrato bancario de préstamo que la sentencia justa en un caso de asesinato o violación.

Lamento que, en España, los procesos penales sigan demasiadas veces los derroteros a los que acabo de referirme, pero no por ello debo modificar lo que, junto con otros muchos autores, entiendo que es el principio de oficialidad. 
el aforismo, en el sentido de que el juez, el tribunal, no actuará o, lo que es igual, el proceso no se iniciará, si no hay un actor, alguien que insta el proceso, alguien que, con una actuación concreta, de petición al órgano jurisdiccional, hace pasar el proceso de la potencia al acto.

Esta primera consecuencia del principio dispositivo es resultado natural de dos factores: la total instrumentalidad del proceso respecto de derechos e intereses predominantemente privados o individuales, por un lado y, por otro, el libre poder de disposición del sujeto jurídico sobre lo que puede ser materia de aquél. Sólo se iniciará un proceso relativo a la protección de un bien jurídico mío si yo quiero verlo tutelado jurisdiccionalmente. La parte pasiva, el demandado, que, en cuanto tal, sólo tiene, como regla, derechos procesales, es también titular soberano de esos derechos, siempre que -de ese supuesto partimos, insisto- en el proceso únicamente estén en juego derechos e intereses legítimos de unos concretos sujetos jurídicos.

Iniciado el proceso por el actor, que pide tutela jurisdiccional, no se discute que el poder de disposición de ese actor le permite renunciar a obtener lo que ha pedido (salvo que la renuncia, excepcionalmente, esté excluida), del mismo modo que la parte pasiva puede allanarse, es decir, mostrarse conforme con que, frente a ella, se conceda al actor lo que ha pedido. En los dos casos, la decisión vincula al juez, que deberá absolver o condenar, respectivamente. Además, por su disposición sobre el proceso, ambas partes o sólo el actor, hasta cierto momento procesal, pueden hacer terminar aquél sin resolución sobre el objeto (desistimiento).

Algunos sitúan en lo que acabo de escribir el límite del alcance máximo del principio dispositivo. Pero, a mi parecer, el mismo poder de disposición sobre el derecho del que alguien es titular implica y se extiende a disponer de los fundamentos fácticos y jurídicos de ese derecho. Precisamente porque mi derecho es mío, porque mi acción es mía, me corresponde disponer de los hechos y de las normas en que podría fundamentar mi derecho y mi acción ${ }^{9}$. Así, el mismo principio procesal (el dispositivo) fundamenta también, pienso, que el objeto del proceso venga concretamente determinado, ante todo, por lo que el actor decida pedir, pero precisamente en relación con los fundamentos de hecho y jurídicos que quiera alegar. Acabará de perfilarse el objeto procesal según lo que la parte pasiva quiera hacer valer, usando también de su poder de disposición,

\footnotetext{
${ }^{9}$ Para mi posición sobre la acción, $v$., in extenso, El derecho a la tutela jurisdiccional. La persona ante la Administración de Justicia: derechos básicos. Bosch Casa Editorial, Barcelona, 1980, passim. Con la máxima brevedad, en mi última obra general, Curso de Derecho Procesal Civil, I, Parte General, con Díez-Picazo Giménez (I) y Vegas Torres, (J). Edit. Universitaria Ramón Areces, Madrid, 2012, lección sexta, pp. 125-141.
} 
tanto sobre sus derechos sustantivos y materiales como sobre los procesales ${ }^{10}$. Para referirse a estos aspectos del principio dispositivo, es tradicional en España hablar de principio de "justicia rogada" o de "rogación".

Que la sucesión de actos del proceso verse sobre aquello que las partes quieren hacer valer disponiendo de todos sus derechos en la forma que se acaba de decir, esto es, que el proceso tenga por objeto, no sólo las pretensiones formuladas (lo que se pide), sino, más precisamente, las pretensiones con sus respectivos fundamentos fácticos y jurídicos (la causa de pedir), lo considero asimismo una consecuencia del principio dispositivo, aunque -lo reconozco de buen grado- no enlace con el núcleo de dicho principio de modo tan directo, claro e insoslayable como la iniciativa del nacimiento del proceso y la posibilidad de renunciar a obtener la tutela jurisdiccional solicitada. Por distintas razones y motivos, cabe entender, adicionalmente, que es un método procesal razonable y coherente con el núcleo del principio dispositivo, atribuir a las partes la carga de aportar las pruebas de los hechos en que apoyan sus pretensiones, estableciendo, para la sentencia, en caso de falta de certeza, las reglas de la denominada carga de la prueba material: a cuál de los litigantes perjudica la falta de prueba sobre un hecho relevante.

Para aquellos que, con criterio distinto del que acabo de exponer, entienden que la virtualidad del principio dispositivo supone sólo la necesaria iniciación del proceso civil a instancia de parte, la libre configuración de una pretensión de tutela jurisdiccional y la permanencia de un poder de disposición que permite la renuncia del actor, con efectos absolutorios, y el allanamiento del demandado, con efectos condenatorios, será otro principio procesal distinto, denominado de "aportación de parte" el que determina que corresponda principalmente a las partes alegar y probar lo que fundamente sus pretensiones y explicaría que el juez deba dictar sentencia conforme a los hechos alegados y las pruebas aportadas por los litigantes. Y si se grava a las partes con la carga de alegar los hechos y los fundamentos de derecho de su posición, sujetando al juez en la sentencia a esos límites, dirán que el proceso responde al principio o máxima "iudex iudicet secundum allegata et probata partium". Poco importa, a los efectos que aquí interesan, que ese brocardo latino no constituya una regla que imponga atribuir a las partes las cargas de alegación y prueba, como ha puesto de relieve

\footnotetext{
${ }^{10}$ Es claro que gravar a las partes con la tarea de precisar, en cuanto a fundamentos fácticos y jurídicos, su pretensión (en el caso del demandante) y su contrapretensión (en el caso del demandado que no ejercita reconvención), supone aligerar muy considerablemente el trabajo del juez siempre que se disponga que su sentencia ha de ser plenamente congruente con las pretensiones de las partes. Como después diré en el texto principal, ese aligeramiento del trabajo del juez me parece muy conveniente, pero, a su vez, la carga de precisar los fundamentos de las pretensiones sólo se puede arrojar razonablemente sobre las partes cuando el proceso es lo que más adelante denominaré un "proceso civil de abogados".
} 
Picó I Junor ${ }^{11}$. Nunca he invocado esas palabras latinas como si encerrasen un irresistible imperativo. Desconfiado como soy desde hace muchos años ${ }^{12}$ sobre cualquier pretendida conjunción de palabras latinas (o en otro idioma) aducida como axioma o como insuperable argumento de autoridad, esas frases sólo me sirven expresivamente de lo que considero una opción estructural y de reparto de funciones, que pretendo justificar racionalmente aquí.

No me produce el menor disgusto intelectual que se prefiera por numerosos autores la noción más restringida del principio dispositivo. Me cabe desear, eso sí, que no les disguste mi preferencia y mi adhesión a la idea más amplia de dicho principio, del que el de "aportación de parte" o el de exigencia de congruencia de la sentencia con las pretensiones de las partes (...iuxta allegata et probata...) serían corolarios. Lo importante es que uno puede encontrar con bastante facilidad, por encima de su cabeza, por así decirlo, ciertos principios, como los que he denominado "jurídico-naturales", porque responden a postulados elementales de justicia o fair play, que capta como imperativos cualquier ser humano que no sea lo que en España Ilamamos un desalmado. Pero otros principios no se pueden hallar, ni fácil ni difícilmente, ni entre aquellos postulados ni en el cielo de los conceptos o en la caverna platónica de las ideas. Son el fruto de una elaboración intelectual, que se nutre, como casi siempre, del esfuerzo personal y ajeno de análisis y crítica respecto de las normas jurídicas y, además, de la reflexión, igualmente crítica, sobre la experiencia y la tradición legal de una determinada sociedad, de un concreto país ${ }^{13}$.

Los principios procesales jurídico-técnicos no son guías pormenorizadas y rígidas sobre estructuración legal y realización de los procesos civiles. Lo diré con muy directas y expresivas palabras ajenas: "las llamadas máximas (AOS: para nuestros efectos, los principios) no tienen existencia real más que en la medida en que se derivan del derecho vigente. Y una legislación saludable, esto

\footnotetext{
${ }^{11}$ En El juez y la prueba. Estudio de la errónea recepción del brocardo iudex iudicare debet secundum allegata et probata, non secundum conscientiam y su repercusión actual, Barcelona, 207. TARUFFO se adhiere a este descubrimiento en Simplemente la verdad. El juez y la construcción de los hechos, Madrid, 2010, p. 43.

${ }^{12}$ Concretamente, desde que comencé el trabajo que me llevó a publicar La conexión en el proceso penal, EUNSA, Pamplona, 1972. Entonces encontré que el repetidísimo brocardo "continentia causae dividi non debet" no era sino una absoluta petición de principio, aunque con raíces históricas importantes y extensas (v. pp. 74-76 de La conexión...). Lo mismo me ha ocurrido con el adagio francés "le criminel tient le civil en état", nunca inventado como axioma (aunque sí utilizado como tal) y desprovisto racionalmente de la fuerza que habitualmente se le atribuía. Por lo demás, desde la Ley № 2007-291, de 5 de marzo 2007, el art. $4^{\circ}$ del CPP francés dispone exactamente lo contrario. Ya se hizo en España algo semejante con el art. 40 de la Ley № 1/2000, de Enjuiciamiento Civil.

${ }^{13}$ La comparatística procesal no es seria y no merece ser tomada en consideración cuando no se asienta sobre estas exigentes bases.
} 
es, una legislación que no codifique teorías, sino que tenga la mira puesta en un fin práctico, tan pronto las hará realidad como establecerá excepciones, según que esas metas prácticas reclamen una cosa u otra.". Así se expresaba (aunque la cursiva es mía) mi muy admirado Friedrich $\operatorname{STEIN}^{14}$ en 1893. Pues bien, mi

\footnotetext{
${ }^{14}$ F. Stein, El conocimiento privado del juez, trad. de De la Oliva Santos, EUNSA, Pamplona, 1973, p. 126. Permítaseme una digresión, casi en confidencia personal, sobre esta obra del maestro alemán. Tuve un buen día, ya muy lejano, la ocurrencia de empeñarme en traducirla, por dos motivos: primero, porque veía que se citaba muy frecuentemente, pero sin que existiera una versión en español, aunque cierto número de autores latinoamericanos habían traducido otras monografías importantes de grandes autores alemanes (e italianos también); segundo, porque me parecía que trataba de un tema que no pasaría de moda y siempre sería interesante, aquí o allá. Fue una decisión muy afortunada, porque esto último se confirmó más allá de lo que podía haber imaginado. Sin exageración alguna: me ocurre que cada día, desde 1973 hasta ahora mismo, me beneficio de las muchas horas que la traducción me exigió. La cuestión de hasta qué punto puede utilizar el juez sus propios conocimientos, no adquiridos mediante el proceso, resultó un hilo conductor para que alguien de extraordinario talento, como STEIN, escribiese páginas no superadas nada menos que sobre los siguientes asuntos: diferencia entre quaestiones facti y quaestiones iuris, las Ilamadas "máximas de la experiencia", premisas mayores fácticas distintas de las premisas menores fácticas (los hechos históricos concretos); papel de esas Erfahrungssätze para la subsunción (¡nada menos!), para el papel del tribunal de apelación y casación; para determinar la específica aportación del perito y su diferencia con la del testigo; para el concepto de notoriedad, etc.
}

Se ha dicho por personajes de mucha autoridad que un buen libro, un libro excepcional, enseña y forma más que muchos libros normales. En parejo sentido, escuché personalmente al maestro romanista Álvaro D'ORS decir que resulta más formativo aprender una cosa difícil que cien fáciles. Pues bien, el libro original de STEIN era y es -que lo compruebe el que lo dude- de difícil lectura, muy arduo (así lo reconocía PRIETO-CASTRO en una pequeña nota introductoria a la primera edición de mi traducción). Es un libro que no puede leerse siquiera (ni en español ni en alemán: lo he comprobado con universitarios de lengua alemana) sin estudiarlo a fondo, es decir, sin un esfuerzo intelectual considerable, parándose con frecuencia a pensar lo que quiere decir. Pero, una vez que se ha leído, estudiado y entendido, resulta deslumbrantemente formativo e inteligente. Y, paradójicamente, también muy claro. El Prof. Jiménez Conde, uno de los primeros procesalistas españoles que leyó con gran atención esta obra maestra de STEIN, no cesaba, en la primera lectura, de escribir a lápiz observaciones, casi todas interrogativas, al margen de párrafos de muchas páginas. Me contó que, tras una segunda lectura, iba eliminando esas observaciones con una goma de borrar. De ahí que le encomendase una introducción extensa (a mi parecer, excelente) en la segunda edición, a cargo de "Editorial Centro Estudios Ramón Areces", Madrid, 1990. Una característica que añade más valor a la obra de STEIN es que, desacostumbradamente, estudie los asuntos en el doble ámbito civil y penal. De ahí su subtítulo: "Untersuchungen zum Beweisrecht beider Prozesse."

Quizá por su dificultad y probablemente aún más por considerarlo apriorísticamente "antiguo" y no digno de lectura reposada, el libro de STEIN sigue siendo tan citado como en realidad desconocido. V., por ejemplo, TARUfFo, M., La prueba de los hechos, Madrid, 2002, pp. 219 y 270 . Aunque en esta última página menciona expresamente a STEIN, no puedo reconocer en la descripción de las "máximas de la experiencia" expuesta por TARUFFo, la noción de "máxima de la experiencia" (Erfahrungsatz) inventada por STEIN. Lo que TARUfFo descalifica no es lo que STEIN descubrió, porque para el maestro alemán, expresamente, tan "máxima de la experiencia" es la que se inserta en el "repertorio de conocimientos que el sentido común ofrece al juez" (TARUFFo dixit) como las reglas empíricas procedentes de la más rigurosa y avanzada investigación científica. Por lo demás, a diferencia de TARUFFO no pienso que, a causa de las determinaciones de ADN, por ejemplo, hayamos descubierto recientemente la importancia de la prueba científica. Cierto es que el Proyecto Genoma Humano se pone en marcha en 1990 y sólo 
idea del principio dispositivo, aunque adquirida, claro es, gracias a la doctrina procesal (española y no española), está elaborada y perfilada sobre la base de la legislación procesal civil española, desde al menos 1855 y, sobre todo, sobre la base del conocimiento de la realidad judicial y de la tradición jurídica de nuestro proceso civil. Pero -es importante entender lo que viene a continuación- el principio dispositivo en sentido amplio (o, si se prefiere, el principio de aportación de parte) es una construcción intelectual que se manifiesta perfilada en la ley y que lo mismo puede excluir toda iniciativa judicial de acordar pruebas que ser compatible con cierta iniciativa judicial subordinada, como la de las "providencias para mejor proveer" previstas en la LEC de 1881 (art. 340) y a las que luego me referiré. Como ya he dicho, siempre que se haga recaer principal o primordialmente sobre los litigantes la carga de probar los hechos relevantes y no se imponga al juez el deber (y la responsabilidad: ya veremos este punto esencial) de investigar y alcanzar la certeza a consecuencia de su iniciativa estaremos aún en el ámbito del principio dispositivo o de aportación de parte. Deber judicial de investigación de oficio y papel subordinado de las partes significan, en cambio, que el proceso responde al principio de oficialidad. Así, pues, dentro de cierto marco general, son las opciones sobre algunos puntos-opciones adoptadas prudencialmente, como veremos- las que perfilan los principios jurídico-técnicos y no éstos los que determinan esas opciones.

\section{Opciones abiertas para diseñar el papel y los poderes del JUeZ CiVIL: LA IDEOLOGÍA COMO ELEMENTO INSPIRADOR CONTINGENTE}

Salvo un reciente legislador español (de crasa ignorancia sobre la ciencia jurídica procesal, el Derecho comparado y la experiencia mundial, al que aquí dejaremos de lado), que quiere arrinconar al juez ${ }^{15}$, nadie discute ciertos cometidos como propios del juez en los procesos civiles. Le corresponde al juez admitir la demanda, dirigir el proceso, decidir sobre los medios de prueba,

cinco años antes se había descrito la primera técnica de determinación comparativa de ADN (RFLP: restriction fragment length polymorphisms), hoy superada, pero las pruebas periciales científicas (o científico-experimentales) se remontan a muchas décadas atrás, por no hablar de al menos un siglo.

15 Aludo al "legislador" que alumbró la Ley № 13/2009, de 3 de noviembre, de reforma de la legislación procesal para la implantación de la Nueva Oficina Judicial (NOJ: así han dado en llamarla). Mi oposición a esta reforma, con la gran mayoría de los procesalistas españoles, es bien conocida. Al respecto, puede consultarse mi trabajo, "Sobre la calidad de la Justicia en España", en International Journal of Procedural Law, ed. Intersentia Publishing, Vol. I. 2011, pp. 38-42. Adicionalmente, el pensamiento (i!) subyacente a esta reforma, del que existe plena constancia escrita, es que los jueces están (sólo) para dictar sentencia. ¿Hace falta decir que, ante tal "pensamiento" -rechazado por buen número de jueces, pero aceptado por la mayoría- carece de todo sentido la cuestión de los mayores o menores poderes del juez y el debate mundial sobre esa cuestión? Por lo demás, la NOJ ha resultado en un fracaso clamoroso. 
presenciar la práctica de la prueba y dictar sentencia o las resoluciones que ponen fin al proceso con declaración de derechos o efectos similares, procesales y jurídico-materiales.

En cuanto a la dirección del proceso, no resulta dudoso que, en conjunto, incumbe al juez, puesto que es axiomático que el Derecho se diga en los diversos casos mediante un insoslayable método, que es, cabalmente, el proceso. Se trata de un verdadero axioma porque resulta patente y no precisa demostración que no cabe una justicia humana instantánea o sumarísima que se pueda llamar justicia sin incurrir en falsedad. Un juicio inmediato o sumarísimo es lo que en español llamamos juicio temerario. $Y$ en nuestra lengua se utiliza mucho la expresión (que tengo por nativa del foro judicial) "hablar sin conocimiento de causa" para referirse al que lanza afirmaciones contundentes sin datos y ciencia que las respalden. Así, pues, es propio (y exclusivo del juez), en el ejercicio de la potestad jurisdiccional que sólo a él se confiere o, en otros términos, en el cumplimiento de la función jurisdiccional, decir el Derecho (ius dicere) y no sólo el material o sustantivo, sino también el procesal, en tanto en cuanto éste regule lo que es necesario, como método razonable y justo, para garantía del acierto de la sentencia o resolución similar.

Dicho lo anterior, me apresuro a añadir que, además del principio dispositivo, entendido como ha quedado apuntado, que personalmente prefiero como inspirador para la generalidad de los procesos civiles, caben otros planteamientos distintos, que, en sí mismos, estimo defendibles y respetables.

Tras la necesaria iniciación del proceso por quien requiere una tutela jurisdiccional para un bien jurídico suyo (o que, aun no siendo suyo, tiene título para proteger), los roles más concretos de las partes y del juez podrían fijarse de diferente manera sin afectar al más primario poder de disposición de los sujetos jurídicos.

En teoría, podría no exigirse al demandante que concretase el contenido de su pretensión de tutela, limitándose a exponer su caso y a solicitar la tutela que fuese "procedente en Derecho" o fórmula similar. También podría requerirse del demandante sólo una sencilla y muy elemental fundamentación de su pretensión, pero sin necesidad de expresar con mínima claridad a qué título jurídico (o títulos) se acoge y cómo enlazan con ese título ciertos hechos alegados. Asimismo, en teoría cabría dejar al órgano jurisdiccional la labor de descubrir si hay o no hechos ciertos y normas jurídicas que fundamenten la concesión de tutela jurisdiccional, en general, o la concesión de la tutela que concretamente se ha pretendido. En todas esas opciones, el papel del juez sería de mayor importancia y sus poderes serían también mucho mayores.

Llego así al punto o momento clave para establecer un aspecto importante de mi personal posición sobre el papel del juez y sus poderes. Y ese aspecto se puede expresar afirmando que las posibles opciones que acabo de enunciar no 
obedecen necesariamente a postulados políticos o ideológicos. Sería ciertamente totalitario que, por ejemplo, la tutela jurisdiccional civil de bienes jurídicos de sujetos determinados, sin implicación de un verdadero interés social, fuese dispensada ex officio por el aparato del Estado a su arbitrio, sin participación o con una participación únicamente nominal por parte del sujeto jurídico que afirma necesitar tutela en razón de sus propios derechos e intereses legítimos. No me sentiría libre con un Estado que decidiese, sin mi voluntad o contra ella, protegerme de un deudor mío (probablemente, se trataría de un Estado en que mi titularidad sobre un derecho de crédito dinerario no estaría clara). Y ni que decir tiene que también consideraría totalitario atribuir a autoridades administrativas, no independientes, la última palabra en la tutela jurídica de los derechos e interés legítimos de Ticio, Cayo o Sempronio. Pero, fuera de estos u otros similares supuestos, siempre que se reconozcan y respeten la titularidad de los derechos subjetivos de particulares y el poder de disposición de los sujetos jurídicos sobre sus derechos e intereses legítimos, así como la libertad de una razonable actuación procesal de las partes respecto de esos derechos e intereses suyos ${ }^{16}$, no veo que exigir menos a las partes y gravar más al juez derive necesariamente de una posición ideológica que desdeñe la importancia de los sujetos individuales o desprecie la libertad personal en favor de un extraordinario predominio del Estado o de una concepción de la vida social eminentemente estatalista.

Se me ocurre una hipótesis como ejemplo. Imagínese que Austria estuviese dividida en 18 Estados y no en 9. Sigamos imaginando que cada uno de esos pequeños Estados tuviese su propia Justicia y su propio sistema procesal, con personal y medios materiales dignos y suficientes. A mí no me parecería en modo alguno contrario a un exquisito respeto a la dignidad y a la libertad per-

\footnotetext{
${ }^{16}$ Se puede decir, al hilo de las frases que acabo de escribir, que entrañan una concreta opción ideológica. Y cabe que otros opongan contra la totalidad de mi tesis, que nada es ajeno a una ideología o incluso -es una posición de antiguo conocida por mí- que "todo es política". A la posible primera objeción respondo diciendo que, obviamente, han existido y pueden seguir existiendo concepciones de la vida humana y de la sociedad negadoras de los derechos subjetivos individuales y, por tanto, negadoras del poder de disposición que comporta la concreta titularidad de esos derechos. A mi parecer, unas tales concepciones del hombre y de la sociedad y del Estado exceden del pluralismo al que yo hago referencia al hablar de posiciones ideológicas diversas. Es decir, que admito que mi posición es, en cierto modo, ideológica, pero en un contexto histórico obsoleto en Occidente. En este trabajo -y en mi vida, desde hace mucho tiempo- no tomo ya en consideración las ideologías marginales a esa noción de la vida democrática que está indisolublemente vinculada a la dignidad, a la libertad y a los derechos de la persona. En cuanto a que todo sea política o todo sea ideología, siempre me ha parecido, como apreciación de la realidad, una errónea exageración extrema de una posible influencia (a no ser que la biología o la anatomía y el amor y la emoción estética, por ejemplo, se consideren parte de la política o de la ideología). Y si la afirmación se presenta como postulado imperativo, lo rechazo cabalmente como totalitario, porque, a mi entender, amplios aspectos de la vida humana son, y quiero que sigan siendo, ajenos a los distintos planteamientos posibles acerca de la sociedad y del Estado.
} 
sonales que en uno o en varios de esos Estados, con poca población, existiese un sistema procesal civil en el que, en primera instancia, al demandante sólo se le pidiese narrar los hechos y formular genéricamente su pretensión sin necesidad de fundamentarla jurídicamente y al juez le correspondiese, en cambio, la tarea de llevar a cabo las averiguaciones pertinentes sobre los hechos narrados que considerase relevantes, sin perjuicio de las pruebas que el demandante quisiese aportar. No consideraría derivación de una ideología totalitaria que, además de lo dicho, la búsqueda y selección de posibles normas aplicables al caso fuese asimismo una exclusiva responsabilidad del juez, de modo que la sentencia no fuera reprochable por incongruencia siempre que constituyese una respuesta coherente con la genérica pretensión del demandante y con el caso por él expuesto, incluso si se fundase en un hecho, relacionado con ese caso, cuyo conocimiento cierto resultase ser fruto exclusivo de la investigación fáctica judicial.

No me resulta inconcebible ni deplorable imaginar que un pueblo de hombres libres bien conscientes de ello construyese un modelo de proceso civil como el que acabo de esbozar. Bien podría ese modelo fundarse en una extendida y arraigada confianza popular en un juez sabio y diligente, que una especie de senado designase, temporal o vitaliciamente, de entre los mejores y más ilustrados ciudadanos. ¿Por qué ese modelo procesal habría de ser necesariamente contrario a la libertad y producto de un pensamiento y un designio autoritario o totalitario?

Esta posibilidad de desconexión de la configuración interna del proceso con postulados ideológicos - desconexión que defiendo singularmente en lo que aquí nos interesa, esto es, el papel más o menos activo del juez civil y sus mayores o menores poderes-, no significa negar que desde un punto de partida estrictamente ideológico o político sea posible desplegar, con coherencia interna, una consecuencia o serie de consecuencias en el plano de las construcciones legales y de las realidades procesales. No afirmo que no pueda haber o no haya habido modelos legales de inspiración ideológica. Conozco sólo a grandes rasgos la polémica sobre el pretendido sustrato ideológico-político del Codice di Procedura Civile (CPC) italiano, así como las apreciaciones sobre la inspiración ideológica de la ZPO austríaca bajo la influencia del pensamiento y la obra de Franz KLEIN. Mis escasos conocimientos en esos dos asuntos no me permiten adoptar una posición rotunda en esas polémicas, lo que, por lo demás, me parece innecesario para la defensa de lo que pienso desde hace muchos años, esto es: que, aunque algunos puedan fundar $y$, de hecho, funden sus posturas acerca del papel del juez y de sus poderes en el proceso civil en imperativos o presupuestos ideológicos, es igualmente posible y absolutamente legítimo (y preferible, lo adelanto ya) que la propia opinión sobre el tema que nos ocupa obedezca a razones y motivos ajenos a las ideologías. 
Un corolario lógico de lo anterior, que estimo de gran importancia, es el rechazo más firme a toda taxonomía ideológica o política que se fundamente en la opción relativa al papel del juez y a sus mayores o menores poderes en el proceso civil. Del mismo modo que no acepto que se tache necesariamente de enemigos de la libertad o de totalitarios (e incluso de autoritarios) a quienes postulen para el juez civil mayores poderes de los que personalmente considero prudente conferirles (en determinado país y en un momento histórico determinado), no acepto tampoco que se tache necesariamente de neoliberal, neocon o decimonónico a quien opte por un papel judicial poco activo en la determinación de los hechos y menos aún admito que se le vitupere ideológica o políticamente con desagradables etiquetas.

No es que, poseído más o menos súbitamente de un inmenso afán conciliador, quiera yo creer que todos los procesalistas son personas ideológica o políticamente asépticas o neutrales o simplemente centristas. Seguramente ha habido, hay y habrá procesalistas adscritos o adscribibles a muy diversas posiciones del arco ideológico-político. Lo que afirmo es que las opciones de los cultivadores del Derecho Procesal sobre el papel del juez y sus poderes en el proceso civil no están determinadas necesariamente por su ideología o su posición política. Complementariamente, sostengo que las opciones por mayores o menores poderes del juez civil no constituyen señas de identidad ideológica o política.

Insisto: establecer criterios y normas procesales sobre la base de posiciones ideológicas es perfectamente posible. Sin remontarnos al pasado, cabe observar que, a partir de la denominada "ideología de género", se puede defender y se puede lograr establecer normas especiales de carga de la prueba que, por ejemplo, supongan prácticamente una inversión de dicha carga a favor de las mujeres. Sin embargo, también es posible defender ciertas particularidades sobre la carga de la prueba (sin llegar a la inversión total, a todas luces poco equitativa) en asuntos de violencia contra la mujer, no ya sin suscribir los planteamientos de la "ideología de género", sino incluso rechazándolos.

Iré terminando este aspecto de nuestro tema con un ejemplo que conozco bien. En 1939, Piero Calamandreı publica en la Rivista di Diritto Processuale Civile, Vol. I, su después muy famoso trabajo, La relatività del concetto di azione. Durante un tiempo tuve serias sospechas de que ese trabajo era también, como otros, más citado que leído o, al menos, leído con mínima atención. Después, supe con certeza total que, en efecto, no faltaban los que citaban e incluso invocaban este ensayo de Calamandrei sin haberlo leído en absoluto, puesto que traían a colación la relatividad del concepto de acción, sostenida por CALAMANDREI, para quitar importancia al tema, como si ésa fuese la tesis del maestro de Florencia: tomaban lo relativo en equivalencia a lo escasamente importante, cuando, en realidad, lo relativo significaba y sigue significando lo 
que dice o guarda relación. Y sabemos que, en 1939, el concepto de acción era para CALAMANDREI de extrema importancia, precisamente por la relatividad de ese concepto respecto de posiciones ideológicas neta y duramente opuestas en aquellos tiempos.

Hoy puedo reafirmarme de nuevo, muy sintéticamente, en lo que defendí públicamente en 1974 y publiqué seis años después ${ }^{17}$, a saber: que si bien era y es inteligible y certero el núcleo de la observado por CalamAnDReI (la coherencia de concebir la acción como derecho abstracto con una posición general autoritaria y estatalista y, al contrario, la armonía de la acción como derecho concreto con una ideología antiautoritaria y, en ese sentido, liberal), cualquiera de las dos opuestas teorías sobre la acción puede asimismo fundarse en argumentos no ideológicos y de estricta técnica jurídica, de modo que una taxonomía ideológico-política de los autores en razón de su opción respecto de la acción arroja resultados erróneos y, en ciertos casos, risibles. Ni quien defiende la acción como derecho abstracto era o es necesariamente comunista o socialista ni quien entiende la acción como un derecho subjetivo público de contenido concreto era o es necesariamente liberal.

En España, la Falange, movimiento político estrechamente ligado al franquismo y habitualmente considerado, con alguna imprecisión, pero no sin motivos, como equivalente del fascismo mussoliniano, fue radical y contundentemente partidaria de un juez civil dotado de los máximos poderes. Debemos a una historiadora, Mónica LANERO TÁbOAS ${ }^{18}$ el conocimiento de los Anteproyectos que se elaboraron por la Falange en 1937 para el futuro de la Justicia española. En el relativo a la Justicia civil, se propugnaba la completa desaparición del principio dispositivo o "de rogación" para los procesos civiles, "siendo el juez quien sustituye a los particulares en la dirección de la litis, mientras que en el proceso penal se encomienda la instrucción al Ministerio Público. El papel del abogado también se transforma radicalmente: 'su misión no debe ser ganar el pleito sino defenderlo, no conseguir la sentencia favorable, sino colaborar lealmente en la construcción de la sentencia justa' [dice LUNA, en La revolución judicial Salamanca: Imprenta Núñez, 1938, p. 22]. Porque el nuevo proceso se basa en el principio de veracidad -descubrir la Verdad es la tarea primordial de la actividad judicial- y por ello exige la supresión de trámites procesales que obedecían a otras consideraciones, como garantizar el derecho del acusado o el predominio de las pretensiones de las partes. Se diseña, pues, en los Antepro-

\footnotetext{
${ }^{17}$ Cfr. De La Oliva Santos, Sobre el derecho a la tutela jurisdiccional,.. cit., pp. 28 a 36 y ss.

${ }^{18}$ LANero Táboas, M., Una milicia de la justicia. La política judicial del franquismo (1936-1945), ed. Centro de Estudios Constitucionales, Madrid, 1996, pp.. 78-81. La cita concreta aquí incluida es de un trabajo más breve de la misma autora, accesible en internet: http://ebookbrowse.com/monica-lanerotexto-pdf-d66078317.
} 
yectos falangistas un procedimiento abreviado, de marcado carácter inquisitivo tanto en el proceso penal como en el civil, y con escasas garantías". Podría detenerme más en esta porción de historia, pero lo considero innecesario.

Con todo esto, me parece ya sentado un criterio personal muy firme sobre la cuestión polémica de que aquí se trata: la posición sobre el papel del juez y sus poderes en el proceso civil puede, sí, obedecer a posiciones ideológicas, pero cabe asimismo que nada tenga que ver con tales posiciones y no es acertado, por tanto, ni deducir posturas ideológico-políticas de lo que se defienda sobre nuestro asunto ni sostener que la opción sobre los papeles de juez y partes es consecuencia necesaria de posiciones ideológicas. Con otros términos: postular un papel judicial sumamente activo y ser partidarios de atribuir al juez civil grandes poderes no supone necesariamente totalitarismo, fascismo, comunismo o socialismo (más, para los demagogos de izquierda, progresismo, palabra mágica de virtualidad santificadora, como otras con las que se exorciza al discrepante: inmovilista, retrógrado o cavernícola) y, por el contrario, preferir un modelo de actividad judicial menos activo y, correlativamente, gravar con más cargas a las partes no es una consecuencia necesaria de convicciones liberales o neocon o de retornos al pasado (en concreto al siglo XIX, en el que, por lo visto, todo fue malísimo) que, por lo demás, sólo desearían personas intelectualmente discapacitadas. Las ideologías pueden inspirar, pero no son la única inspiración posible de los modelos procesales civiles. En ese sentido, son un elemento sólo contingente ( $y$, a mi entender, no el deseable) en la configuración del modelo de proceso civil.

Hay un muy interesante corolario de este criterio: optar por atribuir al juez civil más protagonismo o, lo que es igual, atribuirle más poderes a causa de un prejuicio o punto de partida ideológico, como, a la inversa, entender que un imperativo ideológico-político liberal obliga a reducir al máximo los poderes del juez, además de constituir un error in principio, dificulta extraordinariamente la mera comprensión de las posturas distintas de la propia sobre nuestro tema (y el consiguiente debate), pero, sobre todo, se alza como un obstáculo imponente para el análisis racional de la cuestión que aquí tratamos y para la formulación de propuestas viables y positivas de distribución de funciones entre el juez y las partes en el proceso civil ${ }^{19}$.

\footnotetext{
${ }^{19}$ Me temo muy mucho, sin embargo, que el propósito de mejorar efectivamente la Administración de Justicia diseñando sistemas procesales viables y mejores que los anteriores (o proponiendo reformas parciales in melius) les resulta a demasiadas personas más arduo que permanecer invariablemente en un análisis de la Justicia mirándola siempre in abstracto y desde fuera (cuando no desde fuera y desde arriba, desde el personal Olimpo). En cuanto a nuestro asunto, es mucho más fácil mantener la polémica artificial y absolutamente abstracta, en la que algunos procurarán imponer sus prejuicios ideológicos y descalificar a quienes no les secunden como párvulos díscolos que no se verían deslumbrados ante una indiscutible sabiduría e infalibilidad del maestro. Con toda razón, algunas personas se negarán
} 
a ser clasificadas como fascistas a causa de la relación entre la fecha del Codice di Procedura Civile italiano y la fecha del propio nacimiento (así TARUFFo, loc. cit. en nota 4, pero v. infra en esta misma nota) o por la semejanza de lo que defienden con los postulados de la Falange franquista. Pero, sin ninguna razón (sólo con motivos que prefiero no analizar), algunas personas no tendrán el más mínimo empacho en etiquetar ideológica o políticamente, de modo peyorativo, a quienes no compartan sus opciones procesales. A eso se le denomina popularmente, en España, la "ley del embudo" (la parte más ancha para mí; la estrecha, para ti). Pero cabría hablar también de ideologización-politización a beneficio de inventario: desideologizo o ideologizo según lo que me interese retóricamente en cada momento. ¿Tengo que decir que ésa no sería la retórica de Aristóteles y ni siquiera la de Cicerón, sino la retórica bien amada por los sofistas?

Le preguntan a TARUFFO (loc. cit., nota 4): ¿Cree usted ya superado el debate jurídico sobre los poderes de instrucción del juez, esto es, la iniciativa probatoria de oficio en el proceso civil? Y responde así: “En mi opinión, este debate no tenía razón de empezar. Porque se habla del principio inquisitorio sin tener en cuenta que jamás existió un proceso civil inquisitorio. Existía un proceso penal inquisitorio, pero no civil. Se juega con el uso retórico de las palabras, porque el término inquisitorio tiene una connotación negativa. De hecho, lo que ocurrió en todos los sistemas procesales, al menos a partir de la segunda posguerra, es admitir muchos de los poderes probatorios del juez. Se hizo, no porque fueran sistemas fascistas o comunistas, simplemente porque el proceso civil puramente dispositivo como demuestran la experiencia histórica y la compartida no es eficiente. No es un buen método procesal, porque no llega a la búsqueda de la verdad, a la correcta aplicación del derecho en la decisión final. Por otra parte, argumentar que el código italiano de derecho procesal civil es fascista porque es del 1940 es una estupidez, significa no conocer nada ni de politología ni de historia. Sería como decir que soy fascista porque nací en 1943. Son argumentos que no tienen ningún sentido. Por eso creo que el debate nunca debería haber empezado. Es un debate puramente ideológico, propagandístico". (la cursiva es mía),

Me parece que esta respuesta requiere matizaciones. No tengo conocimientos suficientes para estar seguro, pero me inclino a pensar, Como TARUFFo, que el debate era ideológico y propagandístico en Italia, respecto de la inspiración del CPC y el pensamiento jurídico-ideológico de sus autores. Lo que ocurre es que el debate sobre el tema de este trabajo, es decir, sobre los denominados "poderes de instrucción del juez" (del juez civil, hay que añadir) y el papel de las partes no es, por así decirlo, un debate italiano, sino internacional: era muy anterior a la última polémica italiana y subsiste al margen de esa polémica. Es un debate que tiene sentido, se plantee como se plantee, aunque uno no considere serio y útil el planteamiento ideológico-político. Por lo demás, ese debate sigue siendo, también fuera del contexto italiano, en gran medida ideológico. Se puede lamentar que así sea, pero no negarlo. Pero lo que resulta llamativo es que, tras negar que el debate tenga sentido y tras considerarlo "puramente ideológico, propagandístico", TARUFFO entre en él, participe en él y lo alimente con fuertes dosis de lenguaje ideológico, que son el único fundamento de un contundente veredicto sobre el sistema procesal civil español, con la LEC de 1881 y con la LEC de 2000 (v. infra, nota 33).

He descubierto recientemente -y lo lamento, pues no pude tomarlo en consideración en mi trabajo de 2010 - un interesante trabajo de PICó I Junor, titulado La iniciativa probatoria del juez civil: un debate mal planteado, en Revista Uruguaya de Derecho Procesal, 2007, № 3, pp. 573-590. Aunque está claro que Pıcó I JunOr es partidario, axiomáticamente, como lo correcto y progresivo, de la iniciativa judicial en el proceso civil, defiende que se llegue a un punto de equilibrio: ni demasiada iniciativa judicial, que lesionaría garantías de las partes, ni una nula iniciativa, que redundaría -le parafraseoen menor eficacia o eficiencia del proceso civil como instrumento del Estado al servicio de la justicia. A mi parecer, este autor formula la polémica en términos demasiado amplios, porque, en realidad, no se discute sobre cualquier iniciativa judicial en material probatoria: es iniciativa judicial y muy importante formular preguntas a testigos y partes cuando sus declaraciones se han admitido como prueba y se observan oscuridades o contradicciones. Nuestro debate tiene, en cuanto a la prueba, una almendra o nuez, una cuestión clave, ya señalada antes en el texto principal, que es si el juez puede y debe, o no, acordar prueba de oficio. Mi planteamiento en 2010 y en estas páginas no tiene nada que ver con el que examina PICó I Junor: pretendo que esa cuestión nuclear deje de responderse, no sólo por ideología o corrección doctrinal, sino también a base de deducciones de los principios pro- 


\section{LA FUNCIÓN PRIMORDIAL DE LA PRUDENCIA PARA ABORDAR Y RESOLVER LA CUESTIÓN DEL PAPEL Y DE LOS PODERES DEL JUEZ CIVIL}

Acabo de hablar de propuestas viables. Si me importa sobremanera la viabilidad del modelo procesal civil resultante de la opción relativa a los poderes del juez es porque descarto que tenga interés jugar a polemizar sobre modelos abstractos, con sus abstractos valores. En ese plano, de pura discusión teórica, no tengo inconveniente en declararme de antemano perdedor de cualquier debate (si se me obliga a participar), no sólo del que ahora mismo podría producirse (o re-producirse) en España, en Italia o en toda Latinoamérica, sino del que, hipotéticamente, se hubiese celebrado hace un siglo o cuatro siglos, en Inglaterra o en un cantón suizo. Pero parto de la base de que no se trata de deliberar en el vacío, utópica y ucrónicamente, sino de analizar y resolver la cuestión como es propio de una genuina perspectiva jurídica, a saber: con practicidad, buscando un resultado posible, que, a la vez, sea razonable y justo. Un debate sin proyección práctica no es un debate jurídico-procesal o, simplemente, un debate jurídico.

El debate jurídico es histórico, es decir, se produce en el tiempo (en un tiempo determinado con sus realidades determinadas) y para nosotros, procesalistas, la viabilidad de las conclusiones es tanto más importante cuanto que no nos ocupamos de situaciones y relaciones humanas y de la regulación que las reconoce, encauza, rectifica o prohíbe, sino de construir y de analizar críticamente unos artefactos o artificios, que no responden a realidad extralegal alguna, sino que son inventados para servir. Así, pues, resulta decisivo que esos artefactos o artificios, que son los procesos, funcionen y sirvan.

Me parece innecesario entretenerme en explicar que, a la hora de las decisiones (la hora de optar), la prudencia es un hábito esencial para orientar la conducta o comportamiento. Tiene un fundamento de miles de años (desde Sócrates, Platón y Aristóteles) la idea de que la prudencia, que el segundo de los citados considera auriga virtutum, es el puente entre lo intelectual y lo agible, entre las ideas y la acción. En nuestro caso, la prudencia habría de ser siempre la clave para decidir, a partir del conocimiento, de la ciencia, pero ponderando todos los aspectos de la realidad histórica en cada país, qué papel atribuir a las partes y qué otro al juez. En el juicio y en la decisión prudencial es esencial el conocimiento y la valoración de la realidad, con una fundada previsión de la factibilidad y de la eficacia de lo que se puede decidir y hacer en razón del

cesales jurídico-técnicos y, concretamente, del principio de aportación de parte, al que Picó I Junor atribuye decisiva importancia en la polémica. Aquí he procurado describir esos principios procesales con mayor precisión aún que en 2010, pero ya en 2010 estaba meridianamente claro, a mi parecer, que el debate debía afrontarse a base del conocimiento y ponderación de muchos datos, conducente a una decisión prudencial. 
fin que se persigue. Aquí, doy por supuesto que se quiere un proceso civil que, en un tiempo no excesivo, garantice al máximo sentencias bien fundadas, es decir, conformes a la realidad de los hechos de cada caso y a una acertada aplicación del Derecho.

\section{A) Factores que se han de ponderar prudencialmente}

Sentados esos presupuestos, la respuesta a la cuestión del papel del juez (en relación con el de las partes) depende, a mi parecer, de muchos factores. No me atrevo a enumerarlos con pretensiones de aproximarme siquiera a la exhaustividad. Pero unos cuantos factores reales sí resultan fácilmente identificables. Y comenzaré por una faceta de la realidad que quizá otros no abordarían en primer lugar. A mí, sin atreverme a situarla en lo alto del "ranking" de factores relevantes, me parece de suma importancia. Cuando afrontamos qué papel y qué poderes atribuir al juez civil, ¿en qué sociedad nos encontramos? ¿Nos encontramos en una sociedad con abogados o sin ellos? Más concreta y precisamente: esa sociedad, ¿acostumbra a recurrir a los abogados sólo para muy pocos asuntos o es habitual que los abogados intervengan en las relaciones intersubjetivas de índole jurídica?

Si viviéramos en una sociedad sin abogados (o con muy pocos, reservados para muy pocos asuntos: no importa la causa, pero es frecuente que sea el coste total de la Justicia con abogados), resultaría casi imperativo atribuir al juez civil un papel muy predominante de actuación procesal y unos amplios poderes, tanto para acordar pruebas ex officio como para establecer el planteamiento jurídico de los litigios civiles. Porque a los litigantes, en su inmensa mayoría legos en Derecho, no sería razonable imponerles cargas de alegación y prueba que, de ordinario, serían incapaces de levantar.

Supuesto que estemos, por el contrario, en un país de abogados (es el caso de España), ya se adivina que la población, la litigiosidad (cantidad y calidad) y el elemento humano de la Justicia (cantidad y calidad de Jueces, pero también de abogados) han de ser traídos a colación y considerados muy atenta y seriamente para decidir qué papel y qué poderes se asigna a los jueces en los procesos civiles en que no esté presente un intenso interés público. Esos tres elementos han de relacionarse entre sí, de modo que dispongamos de un cuadro de la realidad de la Justicia dotado de notable estabilidad, pues esa realidad no puede ser modificada fácil y rápidamente (con un incremento sustancial del número de jueces o con una reducción asimismo sustancial del número de litigios) y sin efectos negativos (como los de una improvisación de jueces livianamente formados o una importante reducción de las vías jurídicas que una sociedad determinada considera razonables, como, por ejemplo, una eliminación amplia de la doble instancia). 
A esos factores han de añadirse otros complementarios, que perfeccionan la visión panorámica de la realidad sobre la que se ha de operar. Las naciones y los pueblos no son iguales en cultura jurídica y, más concretamente, en cultura judicial. Los españoles, por ejemplo, son mucho más proclives a plantearse acudir a los tribunales que los habitantes de otros países, donde los costes de la justicia resultan más disuasorios, aunque no sea ése, ni mucho menos, el único factor: puede concurrir, por ejemplo, con el hecho de que las infracciones jurídicas y las vulneración de derechos ajenos sean más o menos infrecuentes o con una cultura que, aunque teóricamente sea igualitaria, no lo es a la hora del litigio, en que el poderoso está bonificado socialmente, incluso con una actitud reverencial o conformista del no poderoso, del débil. Todos sabemos que hay naciones en que la población está más imbuida que en otras de la necesidad acuciante $y$, sobre todo, de la posibilidad de una justicia igual para todos, incluso aunque la realidad diste mucho de ese ideal y de ese cálculo de posibilidad. En esos países, apenas hay resignación (o cálculo y "realismo") ante la injusticia que se cree sufrida. Aunque en este punto, como en tantos otros, las cosas pueden estar cambiando a gran velocidad, en España es aún muy fuerte la creencia de que las injusticias deben y pueden remediarse en los tribunales, por mal considerados que estén coyunturalmente según ciertas encuestas. Es revelador que en España, cuando se quiere afirmar que un comportamiento resulta inaceptable, sea muy frecuente utilizar la expresión "eso es de juzgado de guardia".

Importa, asimismo, la mayor o menor utilidad social, en cada país, del arbitraje y de los mecanismos alternativos al proceso judicial para cuestiones litigiosas menores, como los medios para resolver reclamaciones de consumidores y usuarios. Si esas alternativas (encajen o no en el concepto estadounidense de ADR) son eficaces, la ratio juez/número de habitantes revestirá menor importancia que allí donde aquéllas quizá son muy publicitadas pero de escasísima efectividad (en España, por ejemplo, el arbitraje de consumo y la mediación). Esa misma clásica ratio juez/número de habitantes tampoco tiene el mismo significado en los países en que, como en España (torpemente, desde 1985), prácticamente el mismo tipo de juez se ocupa de grandes y de pequeños litigios, que allí donde existe una neta diferenciación entre tipos de tribunales, de modo que los litigios de importancia se sustancian ante unos pocos tribunales, pero otros muchos litigios, cotidianos, por así decirlo, están atribuidos a muchos jueces en tribunales diferentes y de menor categoría.

\section{B) Los jueces: cantidad, calidad y mentalidad}

Dicho lo anterior, se debe prestar una preferente atención al factor humano principal de la Justicia civil, los jueces. En cuanto al número de juzgadores, 
pienso que será suficiente mencionarlo, pues su influencia en la opción principal sobre el papel y los poderes del juez es obvia. Pero no es el número lo único que importa y ni siquiera lo más importante. Quizá aún de más relevancia es la formación judicial que podríamos llamar "promedio", pues en todas partes coexisten (y son disfrutados o padecidos) buenos y malos jueces qua tales, es decir, no mirando a su bondad personal, sino a la bondad o calidad de su trabajo judicial. De nuevo recurro a palabras de Stein: "toda legislación ha de medir el grado de coerción y libertad del tribunal, adecuándolo al valor y la calidad que tiene el personal judicial correspondiente. El que podía concedérsele en tiempo de la compra de cargos, cuando ni los estudios ni ningún examen aseguraban su capacidad científica ni inspección alguna su moralidad, es distinto del que resulta posible admitir en nuestros días" ${ }^{\prime 20}$.

Y también tengo en mucho, como influyente para deliberar y decidir sobre el papel y los poderes del juez civil, un elemento concreto de su formación, que se me ocurre denominar "mentalidad decisoria", en la que, desde luego, influirá la tradición judicial y legislativa del país. Me explico de inmediato.

No da lo mismo que los jueces de un país estén acostumbrados a encontrarse con relativa frecuencia en el trance de resolver con un amplio margen de discrecionalidad (que no mero arbitrio o capricho) o que, por el contrario, sea infrecuente que afronten en sus decisiones otro riesgo que el de aplicar normas que establecen con aceptable claridad y concreción (de ordinario) los supuestos de hecho y las consecuencias jurídicas. Podría pensarse, no sin motivo y razón, que eso depende de las leyes (más numerosas y prolijas, de ordinario, en los países del Civil Law; menores en número y menos minuciosas en el sistema de Common Law, si se me permite por una vez seguir los tópicos divisorios de esos sistemas), pero resulta que la mentalidad favorable o desfavorable a la utilización de facultades o poderes discrecionales (por supuesto, con un criterio rector legal), sí es algo que se da en los jueces, porque, por ejemplo, tanto a finales del siglo XIX como en el pasado siglo XX, como en estos años del siglo $X X I$, ante normas que atribuyen a los jueces españoles facultades de actuación (muy diversas: desde la actuación que requiere explicaciones a un testigo hasta la que sanciona la mala fe procesal, pasando por la que ordenaba imponer condena en costas según se juzgase o no temerario el comportamiento procesal

\footnotetext{
${ }^{20}$ F. STEIN, op. cit., p. 135. Y añado esta observación: que la evolución histórica en punto a formación judicial no siempre es de avance, sino también, desdichadamente, de retroceso, de modo que no son comparables los jueces españoles de hoy, con los de hace treinta años... ni con los alemanes de 1893 (v. supra, op. cit. en nota 15 e infra, nota 38). Por otra parte, en muchos países que se pueden considerar democráticos, no está aún consolidada la de juez como profesión estable (con sus ventajas e inconvenientes) o, lo que es mucho más importante, no se puede afirmar que la independencia judicial esté, incluso en el plano meramente legal, seriamente garantizada.
} 
de demandante o demandado), cabe comprobar si esos jueces se atrevían y se atreven, mucho o poco o casi nada, a aplicar o hacer uso de esas normas. Si los jueces prefieren normas con supuestos de hecho y consecuencias jurídicas taxativamente establecidas; si ha existido y persiste una renuencia judicial a aplicar normas que les atribuyen poderes y facultades que exigen adoptar decisiones "arriesgadas" y si, de hecho, la consecuencia es que apenas se usan esos poderes y facultades, esa realidad se debe valorar adecuadamente y no debe ser ignorada o despreciada.

\section{C) Los abogados: \\ Su influencia y su papel histórico en los procesos civiles}

Puesto que nos estamos ocupando del "factor humano" de la Justicia civil, hemos de volver de nuevo la mirada hacia los abogados. Suponemos, como hemos dicho antes, que estamos en un "país de abogados", un país con un alto número de abogados a los que, por ejemplo, se acude a la hora de contratar, al menos cuando se trata de un contrato de importancia o atípico. Pero, ¿estamos también ante una Justicia civil "de abogados", es decir, en un país en que, más o menos frecuentemente, o bien habitualmente, los procesos civiles, complejos o simples, sobre asuntos de extraordinaria importancia o sobre cuestiones litigiosas cotidianas, se inician y desarrollan con intervención de abogados? ¿Es acaso esa intervención muy limitada o, por el contrario, muy amplia e intensa? Si la situación supone una respuesta afirmativa a las últimas hipótesis, estaremos también ante una Justicia civil con una larga y arraigada tradición de protagonismo de los abogados, puesto que la ley o la costumbre (no jurídica) (o ambas) determinan su actuación como asesores de las partes. Así sucede en España, donde (salvo para la solicitud inicial del procedimiento monitorio), la asistencia de abogado es preceptiva como regla, con escasas excepciones ${ }^{21}$.

Pues bien, si las partes, por imperativo legal o por costumbre, cuentan de ordinario con un abogado que les asesora desde el comienzo del proceso, no será razonable diseñar el papel del juez prescindiendo de esa realidad de la ordinaria "asistencia letrada" de los litigantes. O lo que es igual, no será razonable atribuir a las partes unas cargas de alegación y prueba mínimas, que estarían plenamente justificadas si litigasen directamente. En cambio, si el proceso civil es un proceso de abogados, a las partes se las puede gravar con cargas que legitiman el papel del abogado y suponen un gran alivio de la carga de trabajo del juez.

\footnotetext{
${ }^{21}$ A propósito de los denominados "procesos europeos de escasa cuantía", que no exigen intervención de abogado y se estructuran suponiendo que esa intervención no se da, lo mismo que en el proceso o procedimiento monitorio, ha quedado claro que España, junto a Italia y Grecia, son los países de la UE en que se prevé con mayor amplitud la preceptiva intervención de abogado.
} 
Ciertamente, cabe que, simultáneamente con una cuasi-omnipresencia del abogado en la Justicia civil, exista un cuasi-global malestar social (incluidos ámbitos jurídicos y judiciales) hacia los abogados. No se superará, en todo caso, el sentimiento de varios personajes de Enrique VI, como el secuaz del rebelde Jack Cade, Dick el carnicero, al que William Shakespeare hace decir programáticamente: "The first thing we do, let's kill all the lawyers!" ("La primera cosa que haremos será matar a todos los abogados"). Ninguna revolución ha llegado a hacer efectiva esa propuesta radical. Y propuestas bastante razonables (y desde luego no tan sanguinarias como las de Dick, the butcher), han fracasado, por muchos y poderosos motivos que hubiera para que triunfasen. El realismo y la prudencia pueden, sin duda, propulsar y orientar cambios relativos a los abogados, pero aún no conocemos (yo no logro ni siquiera imaginar) una situación en que sería realista y prudente proponerse, no ya cambios (se van a dar, me parece, en una línea de disminución paulatina de la intervención de abogados), sino la pura y simple supresión de los abogados en el proceso civil. A veces, sin embargo, he escuchado a algunas personas, incluso a colegas universitarios, sugerir propuestas que, en buena lógica, supondrían la supresión de la abogacía: no lo han puesto por escrito, sino sólo verbalmente.

Si no se suprime la preceptiva "asistencia letrada" de las partes en el proceso civil (o si no se reduce a unos pocos casos), lo único razonable es atribuirles una importante función y procurar que la cumplan lo mejor posible. Ahora que llevo ya años sin ejercer la Abogacía, puedo afirmar categóricamente que suprimir o menoscabar esa profesión histórica me parece irresponsable, aunque también lo sea, en parecida medida, omitir lo que conduzca a que los abogados ofrezcan unos servicios de calidad y se comporten conforme a elevados criterios éticos. Es muy deficiente, por ahora, la exigencia de ética a los abogados por parte de sus corporaciones (en España, por los denominados "Colegios profesionales", Corporaciones de Derecho Público) y aún es muy raro que se exija a un abogado responsabilidad civil por negligencia o mala praxis (no sugiero que se produzca un fenómeno de hostilidad procesal civil contra los abogados como el que en muchos países sufren los médicos, por ejemplo, pero hay una gran distancia entre la demasía actual de una constante exigencia de responsabilidad sanitaria por presunta infracción de la lex artis y la menos que escasa exigencia de responsabilidad civil a los abogados).

Esto sentado, procede, como ya apunté, ser coherentes con el hecho de que, de ordinario, los litigantes se convierten en tales e inician los procesos civiles conforme a los consejos de graduados en Derecho a los que, en muchos países, se les exige una seria formación jurídica básica. Se puede o más bien se debe suponer (dejando ahora aparte las reformas convenientes o necesarias para ejercer la abogacía y para controlar la calidad de los servicios) que los demandantes en potencia están en buenas condiciones para ser demandantes en 
acto interponiendo demandas con un contenido que implique un alto grado de precisión en lo que se pide y en la fundamentación de la tutela judicial pedida. Y se puede o, más bien, se debe suponer, asimismo, que ambas partes actuarán con pleno conocimiento de las reglas sobre carga de la prueba y sobre el valor de los elementos de prueba de que puedan disponer. Todo esto, por referirnos ahora sólo a lo que resulta más decisivo en la primera instancia.

Dejo dicho, con lo anterior, que lo que cabe esperar de las partes del proceso civil en razón de sus abogados me parece de singularísima relevancia a la hora de responder a la cuestión del papel y de los poderes del juez civil. Porque ese papel y los poderes correspondientes han de ser armónicos con las cargas y deberes de los litigantes, como enseguida veremos con más detalle.

\section{D) El papel de la prudencia}

He hablado de la prudencia al encabezar este epígrafe. Como la prudencia es el específico hábito por el que se salta de los principios y criterios abstractos a las opciones prácticas, a las decisiones, no hablamos a la ligera de jurisprudencia ni cuando utilizamos el término en el sentido germano de Jurisprudenz, de Ciencia del Derecho, ni cuando lo empleamos, como en España, para referirnos a las sentencias, a la jurisprudencia de los tribunales, al trabajo jurisdiccional. En este último territorio, es casi evidente que cada sentencia, aunque no sea fuente del Derecho objetivo (ni solo ni junto con otras sobre casos semejantes), es una creación jurídica, porque resulta innegable que todo juez, al dictar sentencia salta de las normas positivas y de los principios jurídicos más los criterios hermenéuticos (por no hablar de otros ingredientes generales, como la experiencia) a la decisión sobre un caso concreto, considerados los hechos.

Un juez (normal, no necesariamente portentoso) no es -y nunca lo ha sido, ni en los momentos de la máxima efervescencia revolucionaria francesa- un autómata aplicativo, la mera boca que pronuncia las palabras de la ley. La naturaleza ineludible de su quehacer le lleva a una creación jurídica, la sentencia, distinta de la ley, por respetuosa que con la ley sea esa sentencia. El respeto al Derecho que sólo condiciona al juez independiente no es la pereza de quedarse en la letra de la ley, sin genuina interpretación, sin discurrir sobre la finalidad de la norma en su contexto y sin la debida atención a los detalles de cada caso y a su posible relevancia. El juez hace jurisprudencia porque la prudencia guía su trabajo de decidir y le exige una atenta y esforzada consideración de los diversos materiales, fácticos y jurídicos, de cada caso.

Y algo semejante se descubre (o, más bien, se debería descubrir) en el quehacer del jurista académico, del jurista que hace Jurisprudenz. El acierto de las construcciones conceptuales, de las distinciones y de las relaciones, no radica ni en su originalidad ni en la exhaustividad de los estudios previos ni en la exhibición de erudición (más o menos genuina y relevante) ni en la habilidad 
dialéctica de las discusiones con otros. La calidad y el acierto radican en el servicio que el trabajo científico-jurídico rinde para una adecuada (equitativa, justa, razonable) resolución de problemas reales, resolución que exige, antes, un análisis certero de esos problemas.

Pues bien, la prudencia ha de ser, asimismo, el motor decisivo para las opciones legislativas y, a fin de cuentas, la cuestión del papel y de los poderes del juez en el proceso civil es una cuestión central a la que se ha de responder a fin de diseñar el modelo apropiado de proceso para una determinada sociedad. Todos los factores que hemos expuesto han de ser ponderados prudentemente para lograr un modelo procesal justo y viable. Porque la cuestión que nos ocupa no trata primordialmente de lo verdadero y lo falso: no hay (como fin; la hay como medio) una realidad que conocer, exponer y valorar, sino una realidad que crear, el proceso, la construcción o sistema procesal. El reto no es, por tanto, primordialmente teórico, sino práctico: acertar en el diseño de un artefacto legal que, supuesta su adecuación a criterios elementales de justicia ("principios procesales" de audiencia y de igualdad de armas de las partes), permita, en una sociedad determinada, conocer y resolver litigios civiles con suficientes garantías de acierto en las sentencias, en un tiempo razonable y con el mejor aprovechamiento de los recursos humanos, siempre limitados en número y calidad, que estén verdaderamente disponibles.

VI. DOS CONVICCIONES FUNDAMENTALES DE MI POSICIÓN: LA RELACIÓN ENTRE PODER Y RESPONSABILIDAD Y LA CUESTIÓN DE LA VERDAD EN EL PROCESO CIVIL

Tras todo lo dicho hasta ahora, antes de afrontar el desenlace de este ensayo con la exposición de la personal postura en la cuestión del papel y de los poderes del juez, me parece necesario ocuparme de dos asuntos, expresando mis convicciones al respecto, que quizá sean equivocadas, pero que, dada su firmeza, son dos fundamentos muy importantes de esa postura, hasta el punto de constituir puntos de partida, de los que paso a ocuparme seguidamente.

\section{A) Poderes y responsabilidad:}

\section{Un equilibrio en crisis, pero que debe procurarse}

Por más clara que sea y por indiscutible que resulte la relación entre poder y responsabilidad, está siendo pertinaz desconocerla o despreciarla en nuestro mundo a todas horas y, muy dolorosamente, en estos momentos de crisis global, donde resulta patente, no sólo un brutal desequilibrio entre lo que se puede hacer y se hace y la rendición de cuentas, sino incluso, algo previo, a saber: la extrema dificultad de identificar a los poderosos protagonistas de tantas acciones. Y de ahí que no pueda dejar de referirme a la responsabilidad y a su relevancia con el mayor énfasis de que soy capaz. Ganz kurz: cuando nos planteamos atribuir 
al juez unos poderes (como cuando se trata de atribuírselos al presidente de una asociación, al consejero-delegado de una sociedad o al Jefe de un Estado o de un Gobierno), nunca hemos de olvidar, sino, por el contrario, debemos siempre considerar que los poderes entrañan responsabilidades. Según mi experiencia, casi nunca está presente esta consideración al tratar de los poderes del juez. Y, sin embargo, prescindir de ella es insensato.

No es sensato, en efecto, dejar de tener en cuenta la carga (en sentido vulgar, no jurídico-procesal) que, con los poderes que se les atribuyan, se echa encima de los jueces. Nunca es razonable y prudente cargar a nadie por encima de sus posibilidades, teniendo en cuenta todos los factores pertinentes. Pero, en cuanto a los jueces, su papel y sus poderes, ante cada proyecto, ante cualquier diseño de modelo procesal civil, resulta obligado afrontar con objetividad este interrogante: ¿están los jueces reales, todos o la inmensa mayoría de ellos -porque no se diseña o se legisla para uno o unos pocos-, en condiciones de asumir la responsabilidad que entrañan las atribuciones previstas en el proyecto o modelo? ¿Podrán hacer uso de los poderes que se piensa otorgarles con una determinada finalidad, siempre que haya de cumplirse esa finalidad? Y cuando utilicen mal o no utilicen indebidamente esos poderes, ¿será factible y equitativo exigirles responsabilidad? Porque se ha de procurar, me parece, que, sin heroicidades, la inmensa mayoría de los jueces usen sus poderes y facultades conforme a las previsiones legales de modo habitual u ordinario y es indeseable que sólo unos pocos jueces los usen de vez en cuando. Visto y dicho de otro modo: hay que pensar en que se pueda reprochar con razón a los jueces no haber hecho uso de sus poderes y facultades, sin que éstos tengan la fundada excusa de que, si los usasen siempre que fuese legalmente procedente, se verían impedidos de resolver en tiempo razonable los casos que les han correspondido. Pero no resulta jurídicamente admisible quedarse en un reproche social inexcusable. Salvo que se acepte algo tan inaceptable como la irresponsabilidad de cualquier poderoso por el uso de su poder, al juez civil a quien se gravase con el deber de agotar el esfuerzo probatorio habrían de exigírsele responsabilidades jurídicas si hubiese causado daño con su juicio sobre los hechos por insuficiencia de la prueba. Si no se considera razonable y equitativo exigir esa responsabilidad al juez civil, tampoco será razonable ni equitativo atribuirle aquel deber.

B) La cuestión de la verdad en el proceso civil

1) Verdad y reparto de "roles" en el proceso civil: La necesidad de una cierta "modestia epistemológica"

El simple enunciado de este subepígrafe, en un trabajo con las características del presente, debe hacer pensar que una cuestión tan capital como la verdad sólo será aquí tratada con estricta limitación al tema que nos ocupa: reparto de 
funciones o papeles entre el juez y las partes y correlativos poderes del juez. Pero no puedo ni quiero en modo alguno eludir la cuestión de la verdad, que atañe principalísimamente a la prueba ${ }^{22}$.

Es frecuente que la necesidad de establecer la verdad del caso real que es objeto de un proceso civil sea considerada, con razón, un punto fuerte, si no el más influyente, de las posturas favorables a atribuir amplios poderes al juez y a conferirle un papel de protagonismo muy superior al que derivaría de lo que, erróneamente -según espero haber demostrado-, aparece como un postulado ideológico liberal y antiautoritario de una supuestamente necesaria influencia en el modelo procesal civil. Un gran protagonismo judicial y unos amplios poderes en cuanto a la prueba no se corresponderían, en todo caso, con el entendimiento amplio, antes expuesto, del principio dispositivo o, cuando menos, se opondrían al denominado "principio de aportación de parte". Por mor de una seria pesquisa sobre la verdad de las cosas o de la necesidad de conocer la verdad, el juez, suele decirse, tendría que poder acordar pruebas de oficio, incluso si se admitiese que, vinculado por el ámbito de los hechos que los litigantes hubiesen querido alegar en virtud de su poder de disposición, esas pruebas acordadas y practicadas ex officio hubiesen de circunscribirse a hechos previamente alegados por las partes.

\footnotetext{
${ }^{22}$ Llevo mucho tiempo insistiendo, de palabra y de obra, en la importancia de la prueba. Además de haberme ocupado en 1972 -van ya cuarenta años- de traducir una de las obras más importantes de la literatura jurídica sobre la prueba, el aquí tan citado libro de STEIN, en el tercer volumen de mi primer libro de texto, Lecciones de Derecho Procesal, III. El objeto del proceso civil. Los actos del proceso y sus efectos. Los recursos ordinarios. PPU. Barcelona, 1983, 214 pp., ya afirmaba lo siguiente: "No debería ser necesario encarecer la relevancia de la prueba. Pero la realidad cotidiana -tanto de nuestros tribunales como de nuestras Facultades de Derecho- aconseja no apresurarse a considerar evidente casi nada. Primero, por los sujetos jurídicos, al relacionarse entre sí: han de pensar en la posible necesidad ulterior de lograr que un órgano jurisdiccional tenga unos hechos como ciertos o verdaderos (cuidar la forma de los contratos, la llamada prueba preconstituida). Segundo, por los abogados: las alegaciones fácticas han de formularse teniendo en cuenta las pruebas de las que se dispone... y aquéllas de las que dispone o puede disponer la parte contraria...Tercero: por los jueces: además de acomodarse a los imperativos de la inmediación, deben acertar en la admisión y en la inadmisión de los medios de prueba... Además, es de suma importancia que hagan uso -y uso adecuado- de sus facultades de intervención en diversos medios de prueba, como la confesión o el interrogatorio de testigos. Si no es el juez quien admite los diversos medios de prueba, ni quien presencia su práctica, ni quien decide si son procedentes o improcedentes determinadas preguntas, si no aclara los aspectos oscuros de las declaraciones de las partes y de los testigos, etc., la prueba civil se convierte en una serie de actuaciones rituales, en exceso encorsetadas y excesivamente aleatorias en su resultado. $Y$, a falta de una actividad probatoria seria, que permite y aun exige o comporta inevitablemente una valoración igualmente seria de la prueba, es fácil que la determinación relativa a la certeza, positiva o negativa, o la duda sobre los hechos, se adopte según impresiones precipitadas y subjetivísimas y, con no poca frecuencia, por prejuicios, por algún maniqueísmo o voluntarismo (se tiende a tener por cierta la versión de la parte a la que se quiere favorecer, aunque esta voluntad no sea reflexiva y, por tanto, no se incurra en estricta prevaricación)".
} 
Ésta es la repercusión sobre nuestro tema que habitualmente presenta la cuestión de la verdad. Me parece muy conveniente, antes de seguir adelante, exponer dos precisiones al respecto. La primera consiste en señalar algo tan sabido como que esa cuestión es uno de los más importantes tópicos de la reflexión y de la ciencia humanas, comenzando por la filosofía. Esto significa -a poco conocimiento que se tenga del pensamiento humano desde el comienzo de la escritura- que sentar una base sólida acerca del interrogante sobre "la verdad de las cosas" y nuestras posibilidades de conocerla, con la finalidad de, sobre esa base, afrontar y resolver el problema procesal del denominado juicio de hecho (o, mejor, juicio sobre los hechos), implica correr el riesgo de no disponer nunca de instrumentos para resolver el problema procesal. Callejón sin salida, cul de sac, dead end. ¿Por qué hablo de un riesgo de parálisis del jurista procesalista por carencia de instrumentos? Sencillamente, porque en el plano filosófico existen posiciones irreductibles (al menos desde Guillermo de Ockam) sobre la realidad y sobre nuestro conocimiento y porque, en el plano científico-experimental, la incertidumbre y la provisionalidad del conocimiento planean sobre cualesquiera métodos de investigación y sus resultados. De modo que la cuestión de la verdad carece de una respuesta unánime o generalmente aceptada que pueda servir de presupuesto a la opción sobre el reparto de "roles" entre juez y litigantes y, más en concreto, al papel de uno y otros respecto de la prueba.

Señalaré, como segunda precisión, que resultaría imposible una explicación suficientemente justificada de la propia posición sobre los poderes del juez y de las partes en el proceso civil si la cuestión de la verdad hubiese de ser tratada con la mínima extensión que merece ese interrogante, en sí mismo considerado. Y, dado que nuestro tema es objeto de controversia, se diría que no cabe tratarlo prescindiendo del contexto archipolémico sobre la búsqueda y adquisición de la verdad ${ }^{23}$. Ahora bien, esto implica un esfuerzo meta y pre-

\footnotetext{
${ }^{23}$ Me parece que ilustraré adecuadamente lo que quiero transmitir si digo que, de autoexigirse un tratamiento del problema o cuestión de la verdad con carácter general como tarea previa a la cuestión de los "roles" de juez y partes, cualquier procesalista no podría ni siquiera abordar el tema de estas páginas sin llevar a cabo una labor como la que supone, por poner un ejemplo real, analizar críticamente las consideraciones y opiniones de TARUfFo en sus obras, La prueba de los hechos y Simplemente la verdad. El juez y la construcción de los hechos, cits. supra., con el añadido de lo que en ellas no aparezca y también sea relevante para la cuestión de la verdad. No me es posible tal labor. Puedo decir, eso sí, que comparto por completo la preocupación y el empeño de TARUFFO por no admitir, en el ámbito del proceso civil, unos sucedáneos o Ersätze de la verdad, constrúyanse esos sucedáneos de un modo u otro. Lo que no comparto es que sus objeciones a los sucedáneos de la verdad y cuanto contienen sus citadas obras conduzcan a descalificar cualquier sistema procesal civil que no atribuya amplios poderes de iniciativa probatoria al juez. Con la seguridad que me proporciona conocer el talante liberal del colega y amigo, me atrevo a echar en falta, en esas tan interesantes obras de TARUFFO, sobreabundantes en conocimientos epistemológicos y en certeros análisis críticos, unas cuantas
} 
procesal extraordinario en el amplísimo campo de la metafísica, de la teoría del conocimiento, de la epistemología, etc. y, además, un espacio de papel o un número de bytes de los que no es imaginable disponer, no ya en un ensayo breve, sino ni siquiera en un grueso volumen.

Mas, como quiera que el ensayo breve sobre nuestro tema es posible de facto (aquí está éste, antecedido por otros) y como, según testimonios fiables, el ensayo no es sólo posible, sino también poseedor (en ocasiones) de interés y de utilidad, tanto informativamente como a modo de estimulante del pensamiento libre y crítico del procesalista, se hace ineludible, no soslayar la cuestión de la verdad, pero sí tratarla con notable modestia epistemológica, como si, more scolastico, recuperásemos la noción de gnoseología y abrazásemos decididamente un tratamiento de la cuestión del juicio procesal sobre los hechos en el plano del conocimiento común (de la $\gamma v \omega \sigma i s$, gnosis) frente al del conocimiento

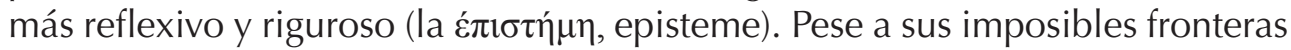
absolutas, nos deberíamos mover más en el ámbito de la gnoseología clásica que en el de la epistemología moderna. Si se me permite una cierta caricatura a efectos expresivos, deberíamos apoyarnos más en Sócrates, Platón y Aristóteles que en Wittgenstein y Popper. Porque, como veremos, la sencillez de los antiguos cuadra mejor con la prueba civil, una búsqueda de la verdad que, guste o no, es irremediablemente instrumental y limitada.

\section{2) La búsqueda de la verdad en el} proceso y el juicio jurisdiccional sobre los hechos

No voy a defender ahora, inmediatamente, la racionalidad y legitimidad $-y$, en definitiva, la prudencia- de no atribuir al juez grandes poderes en materia de prueba y, en concreto, de no permitirle acordar de oficio la práctica de pruebas. Lo que en este momento me importa más dejar establecido es que una y otra opción (muchos o pocos poderes; prueba de oficio, sí o no) nada tienen que ver, si bien se mira, con la antigua y muy manida distinción entre una verdad material y una verdad formal. Nunca he recurrido, por respeto a mi propia (aunque nada original) idea de verdad, a semejante distinción, que considero errónea, no ya filosófica o psicológicamente, sino también en el plano

valoraciones prudenciales que, sin embargo, cabría esperar de quien mantiene la identidad profesional de procesalista, como es el caso.

Sin duda, el maestro de Pavía tiene perfecta libertad para tratar los temas con el enfoque que quiera y, desde luego, no pretendo aleccionarle en modo alguno. La prueba procesal es asunto que considero legítimo tratar a base de epistemología moderna y contemporánea. Pero también es legítimo sostener que, bien mirada, la prueba procesal es una pieza del proceso y éste, como enseguida se dirá en el texto principal, no tiene como finalidad esencial determinar verdades, sino decir el Derecho en casos concretos, de modo que la búsqueda de la verdad es limitada y medio para un fin y no fin en sí misma. 
procesal. Sé que ha sido frecuente, entre los tópicos utilizados acríticamente, referirse a la verdad formal como aquel sucedáneo de la verdad, de la verdadera verdad, que resultaría aceptable en la inmensa mayoría de los procesos civiles, mientras que en algunos procesos civiles y, sobre todo, en el proceso penal importaría, no el sucedáneo, sino la verdad verdadera, calificada como material.

A mi entender, ese planteamiento implica un desacierto multifacético, no sólo por la sospechosa y maloliente ${ }^{24}$ distinción de "verdades", sino por la correlación de esos dos conceptos de verdad con los dos tipos de proceso. Que en los procesos en que sólo están en juego los derechos e intereses legítimos de unos sujetos jurídicos particulares los poderes probatorios se atribuyan a las partes, con sus correspondientes cargas, sin gravar al juez y que, en cambio, se prevea la iniciativa probatoria del juez en los procesos (penales o también civiles) en que está presente un interés público de notable intensidad, nada tiene que ver ni con entender inaccesible la verdad ni con negar la "verdad de las cosas" ni con desinteresarse de la verdad en los procesos del primer tipo y, en cambio, mantener para los segundos la importancia decisiva de la verdad. Lo único que considero acertado sostener es que todo proceso debe entrañar una real y verdadera preocupación por la verdad, so pena de perder su médula ética y dejar, así, de ser instrumento de la administración de la justicia.

Pero la búsqueda de la verdad en los procesos no puede ser y no es igual a la del historiador o a la del filósofo o a la del investigador experimental. Esto se reconoce de palabra y genéricamente con toda facilidad, pero sin coherencia. Hay una muy patente diferencia entre la tarea del juez y la del historiador o la del químico. Pero, por patente que sea, no la vemos suficientemente reconocida o valorada, sino más bien ignorada. Me refiero a que historiador, filósofo o químico pueden prolongar sus esfuerzos en pos de la verdad cuanto su vida les permita (e incluso continuarlos, de algún modo, en el esfuerzo de sus discípulos) y a que esos estudiosos consiguen también resultados útiles, propios de su quehacer (en especial, el científico experimental) mediante la falsación, es decir, cuando comprueban y determinan lo falso o erróneo, pero sin llegar a establecer lo verdadero. Unos y otros buscadores no judiciales de la verdad pueden considerar que avanzan aun cuando su búsqueda conduzca, junto a algunas certezas, también a la persistencia de dudas e incluso a suscitar dudas nuevas. Los resultados de sus trabajos son socialmente útiles (por eso es razonable que los publiquen) en cuanto supongan algún avance en el conocimiento

${ }^{24}$ Se me ha ocurrido utilizar este adjetivo porque, aunque su uso, por infrecuente, Ilame la atención, es, pienso, perfectamente apropiado. Si hablamos en Derecho Procesal del fumus boni iuris, que me gusta traducir como "aroma de buen derecho", lo contrario es, no aroma, sino hedor, algo maloliente. 
de la realidad, es decir, cuando alcanzan certezas parciales, sean positivas o negativas. Son útiles también cuando permiten formular conjeturas fundadas, es decir, probabilidades cualificadas.

En cambio, en el proceso y, en concreto, en el civil, la necesaria búsqueda de la verdad no puede ser prolongada mucho tiempo (y menos aún indefinidamente), porque no constituye un fin en sí misma, sino que es esencialmente instrumental de una decisión sobre un pequeño trozo de historia humana, decisión que debe producirse dentro de un margen temporal no muy extenso e incluso, en algunos ordenamientos jurídicos, en un plazo determinado, porque la sentencia ha de dictarse, por ejemplo, en el plazo de 20 días después de la celebración del juicio (art. 434.1 LEC).

No debería hacer falta añadir que, en todos los ámbitos, la complejidad de muchas realidades y la falibilidad humana conducen a "verdades provisionales", que más adelante se revelan como falsedades o errores. Muchas veces, por muy seria y esforzadamente que hayamos buscado la verdad, no podemos afirmar con rotundidad haberla alcanzado y sólo logramos un estado interior que oscila entre la absoluta duda y la firme certeza, pasando por distintos grados de posibilidad y de probabilidad. La Tatsachenfeststellung, la fijación de los hechos como ciertos (así me gusta traducir el concepto alemán) no va razonablemente, en los procesos civiles como en los penales, más allá de una convicción racional del juez que fundamenta su juicio de certeza de los hechos.

El juicio de certeza es el resultado de la serena convicción de haber hallado la verdad. La certeza no es, pues, una categoría ajena e inferior a la verdad. En cualquier proceso se trata insoslayablemente de lograr un juicio sobre los hechos relevantes para dictar sentencia sobre el objeto procesal. No por labilidad de la verdad, sino por la débil y menesterosa condición del hombre que juzga, he defendido y de nuevo defiendo ahora que el juicio de certeza (positiva: "se han dado estos hechos"; o negativa, muy infrecuente; "no se han dado estos hechos") no tiene por qué consistir en poseer una plena y absoluta seguridad sobre la realidad (o verdad) de unos hechos, sino en una seguridad razonable que excluya la duda. Se ha dicho expresivamente, aunque quizá no con precisión, y lo leemos en LeNT-JAUERNIG, que nos resulta suficiente el juicio de "una tan alta probabilidad que excluya la aceptación de lo contrario". ${ }^{25}$ Es una probabilidad altísima frente a lo tenido inicialmente por sólo posible o meramente probable. No suscribo la definición de LeNT sobre la verdad sino

\footnotetext{
${ }^{25}$ Lent-JauerniG, Zivilprozessrecht, München, 1970, 15 Aufl., p. 149. Los términos exactos son éstos: "eine so hohe Wahrscheinlichkeit, dass die Annahme des Gegenteils ausgeschlossen ist". Me parece que LeNT, al expresarse así, tras el Neuarbeit de JAUERNIG, no consideró necesario estudiar a fondo el teorema de Bayes y la inmensa literatura que lo desarrollaba y analizaba y tampoco la probabilística holista o de otra especie.
} 
que la reproduzco porque es un modo muy fácil de entender que la seguridad absoluta y total es inexigible.

En la misma línea, reproduzco de nuevo a StEIN:

"Nosotros, hijos del siglo XIX, hemos vivido en todos los terrenos científicos tal número de revoluciones y con tal violencia, que forzosamente hemos terminado por aprender a ser modestos. Incluso las verdades matemáticas se han mostrado sometidas al cambio. La geometría euclidiana se demostró como falsa tan pronto como se aplicó a superficies no planas, y tuvo que soportar el verse degradada del

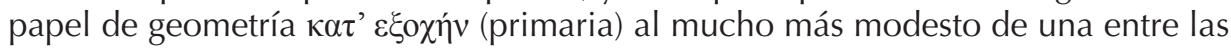
diversas geometrías que existen según los diversos tipos de superficies y que ofrecen entre sí, todas ellas, la misma plenitud deductiva".

"Пóv $\tau \alpha$ $\rho \varepsilon 1$. También el conocimiento de la vida y de la ciencia se encuentra en ese río; tenemos que estar dispuestos a que nuestros conocimientos sean igualmente echados abajo por las generaciones futuras".

Y, después de estas frases, que nos hacen sonreír al pensar que se publicaron hace 129 años (y que el "nosotros, hijos del siglo XIX" puede hoy sustituirse tranquilamente por "nosotros, hijos del siglo XXI", aunque SteIN no profesaba la crédula beatería científica que ahora reina), el maestro de Leipzig entra de Ileno en nuestro tema:

“CCómo lograremos conseguir en el proceso la base firme que necesitamos para poder dictar una sentencia justa? ¿Cómo encontraremos esa base, si nada está quieto y todo se halla en movimiento? La respuesta que nos da el Derecho vigente es la misma para todas las cuestiones similares de la prueba: ninguna prueba puede lograr algo más que convencer a un hombre inteligente que se halle en la cumbre de la formación y cultura de su época... La fuente de errores consiste en que el receptor de la prueba es un hombre mortal, susceptible de errar, y no un Dios omnisciente" ${ }^{26}$.

Stein, con sabiduría, se aparta del probabilismo de LeNT. Y el núcleo de su respuesta es, certeramente, el convencimiento judicial, porque, como apenas acabo de decir, ése es un elemento ineludible: el juicio sobre hechos debe existir dentro de un tiempo limitado y sólo puede conducir a certeza o a duda. Nadie vea en las citas precedentes y en mis observaciones un escepticismo negador de la verdad ni un ápice de cinismo conducente a desinteresarse por ella, con aceptación de sustitutivos funcionales. Sólo hay reconocimiento de la limitada capacidad cognitiva humana ${ }^{27}$.

\footnotetext{
${ }^{26}$ F. STEIN, op. cit., pp. 41 y 42.

${ }^{27}$ Con otras palabras me he expresado hace tiempo, en mi Derecho Procesal Civil. El proceso de declaración, con Díez-Picazo Giménez, Madrid, 2004, § 38, n. 3: "El uso del término verdad debe imponer un saludable respeto. Y no porque no exista la verdad ni existan verdades, ni porque se niegue la posibilidad de conocer una y otras, sino, simplemente, porque su conocimiento es arduo y porque, en nuestra Administración de Justicia y en materia civil (por lo menos), no se exige la adquisición de
} 
Y añado algo de gran importancia: la referencia al convencimiento del hombre inteligente, de que habla STEIN, no significa en absoluto que sea yo partidario -nunca lo he sido- de permanecer en el ámbito de la "libre convicción" como meta deseable de la prueba o de la valoración o apreciación "en conciencia" de las pruebas como modo de extraer de ellas juicios de certeza.

Pese a las expresiones literales de varios preceptos de nuestra Ley de Enjuiciamiento Criminal (el moderno art. 282 bis. 1 y, sobre todo, el art. 741), en el ámbito del proceso penal español (no en otros modelos al parecer ejemplares, como el del veredicto del jurado estadounidense) se ha abandonado ya hace mucho tiempo la idea de que el tribunal puede fijar hechos como ciertos según una libre o "íntima" convicción o según su "conciencia". Ahora se exige, y es exigencia racional y justa, que la certeza positiva o negativa de unos hechos se fije después de una apreciación de las pruebas conforme a las "reglas de la sana crítica", expresión consagrada en distintos preceptos de la LEC 2000, que significa rechazar el subjetivismo y la arbitrariedad y que, sobre todo, enlaza con la necesaria motivación del juicio sobre los hechos, necesaria para el autocontrol y para el control social y jurídico del quehacer judicial. Por lo demás, el "hombre inteligente" y culto al que se refiere Stein no es ni el que se fía de impresiones propias especialmente intensas (con las que llega a una convicción interior inamovible) ni el que fija la certeza arbitrariamente y se esconde tras su conciencia. Ese "hombre inteligente" es el que posee una sana crítica, es decir, la capacidad de un saludable discernimiento y, por supuesto, es también capaz de ofrecer una razonable motivación de su juicio sobre los hechos (el art. 218.2 LEC $^{28}$ ) e incluso podría motivar por qué ha quedado en duda.

Como la duda es, no pocas veces, el resultado del esfuerzo por alcanzar la verdad, en los procesos, tanto civiles como penales, se necesitan normas para resolver en caso de duda sobre hechos relevantes: las normas de carga de la prueba en sentido material y la regla in dubio pro reo. Son normas imprescindibles en todo caso, porque es perfectamente posible e incluso probable que, pese a atribuir al juez poderes de iniciativa probatoria, la duda no se disipe, dejando paso a la certeza. El juez con poderes probatorios puede encontrarse quizá con más tranquila conciencia respecto de su esfuerzo, pero, en general, se

una certeza o de un convencimiento de la verdad de unos hechos beyond any reasonable doubt, 'más allá de toda duda razonable', expresiva formulación angloamericana que la literatura y el cine han popularizado". Y que, por supuesto, como tantas otras singularidades estadounidenses, no se cumplen.

${ }^{28}$ Que dice lo siguiente: “Las sentencias se motivarán expresando los razonamientos fácticos y jurídicos que conducen a la apreciación y valoración de las pruebas, así como a la aplicación e interpretación del derecho. La motivación deberá incidir en los distintos elementos fácticos y jurídicos del pleito, considerados individualmente y en conjunto, ajustándose siempre a las reglas de la lógica y de la razón". Este precepto puede no resultar enteramente convincente en sus propios términos, pero su ratio resulta impecable. 
hallará, a la hora de decidir sobre los hechos relevantes de un caso, en el mismo estado de limitación subjetiva en que se encuentra el juez ante los resultados de las pruebas practicadas únicamente a instancia de las partes. $\mathrm{O}$, por decirlo quizá más exacta y expresivamente, la dificultad de uno y otro juez para formar su juicio sobre los hechos es muchas veces igual o pareja y los riesgos de errar, los mismos o muy semejantes.

A mi entender, lo que una sincera búsqueda de la verdad exige en todo proceso y, más en concreto, en los procesos civiles sobre bienes jurídicos de ciertos sujetos, es un método serio para que el juez esté en las mejores condiciones de juzgar sobre la certeza de los hechos relevantes, en orden a dictar sentencia. Y por "método serio" se debe entender un conjunto de reglas y mecanismos que racionalmente permitan tener como ciertos, a efectos procesales, los hechos relevantes del caso.

En los procesos civiles en que están en juego sólo bienes jurídicos de los litigantes, una parte del método para establecer la certeza procesal de los hechos es el mecanismo de su admisión como ciertos por todas las partes. Los hechos admitidos, incluso tácitamente, se fijan como ciertos y quedan exentos de prueba. Dejando de lado discusiones acerca de la naturaleza jurídica de la conformidad de las partes sobre los hechos (se produzca a la vista de las alegaciones o incluso, con ciertos matices legales, con ocasión de la declaración de las partes como instrumento de prueba), tener por ciertos los hechos que no se discuten no es sólo algo que resulta práctico y justificado, sino un efecto que responde a una máxima de la experiencia según la cual, en asuntos en que están en juego bienes jurídicos particulares, si el demandado, por ejemplo, admite como cierto un hecho personal que, en principio, le resulta perjudicial, es porque, en efecto, el hecho es cierto. La experiencia no dice lo mismo cuando se trata de crímenes, de ilícitos penales: conforme a la experiencia, no faltan autoinculpaciones basadas en muy diferentes motivos, sin relación con la verdad. De ahí que la Ley de Enjuiciamiento Criminal, en su art. 406, pfo. primero, disponga que "la confesión del procesado [léase sospechoso o imputado] no dispensará al Juez de instrucción de practicar todas las diligencias necesarias a fin de adquirir el convencimiento de la verdad de la confesión y de la existencia del delito".

Personalmente, no veo en este modo de fijar la certeza de unos hechos a efectos procesales la aceptación de un sustitutivo o Ersatz de la verdad, sino un método razonable, empíricamente sólido, de alcanzar la verdad dentro de las limitaciones ya señaladas, inherentes al quehacer jurisdiccional, cualquiera que sea el ámbito vital sobre el que ese quehacer se proyecte. Porque, como ya he dicho, hoy en día y desde hace muchos años, ha dejado de tener el más mínimo sentido la comparación entre la pretendida "verdad formal" de los procesos civiles y la "verdad material" de los procesos penales. La comparación entre unos y otros procesos, con resultados que hoy son verdaderamente paradójicos 
y merecedores de más reflexión crítica, no pretende justificar cualquier modo de alcanzar un juicio sobre los hechos en los procesos civiles, como si en ellos ya pudiésemos prescindir de la verdad porque de ella se prescinde en el proceso penal. Lo que aquí pretendo defender es que el método procesal civil de fijar los hechos admitidos como ciertos y exentos de prueba es razonable per se. Y lo mismo cabe decir de la regla de tener como ciertos, sin necesidad de prueba, los hechos notorios. De incoherencias -y no leves, por cierto- relativas a la verdad en el proceso penal (incluso prescindiendo de ella en innumerables casos) ya me he ocupado en otros lugares ${ }^{29}$.

Tras cuanto ya ha quedado dicho, puedo exponer mi personal posición sobre el papel y los poderes del juez civil. Es una posición histórica no sólo en el obvio sentido de que se da en el tiempo, sino también porque depende de coordenadas precisas ligadas al espacio y al tiempo. No pienso que esa posición deba ser compartida si las coordenadas son distintas y seguramente haría mías o adoptaría posiciones distintas en lugares, tiempos y circunstancias diferentes de los de mi país. Mi posición sólo puede fundar o alimentar una polémica real con quienes, para España, difieran sustancialmente de lo que enseguida defenderé. Y, por decirlo una vez más, se me ha de considerar también beligerante-amable pero firmemente beligerante-frente a los que entiendan que, por presupuestos ideológicos indiscutibles, sólo es admisible y acertada, en todas partes, una única postura sobre nuestro asunto: la de atribuir a los jueces una responsabilidad principal sobre la prueba como modo de procurar juicios acertados sobre la verdad de los hechos procesalmente relevantes.

\footnotetext{
${ }^{29} \mathrm{~V}$., en especial, "Presunción de inocencia, prueba de cargo y sentencia de conformidad", en Prueba y proceso penal, Valencia, 2008, pp. 67-74. Publicado también en Revista de Derecho Procesal, 2007, pp. 701-708. En este breve texto, que es el de una ponencia presentada y discutida el 25 de octubre de 2006 en el "Congreso Internacional sobre problemas modernos y complejos de la prueba en el proceso penal", organizado por la Universidad Jaume I, Castellón de la Plana, planteo la colosal incoherencia (al menos en España) de sostener, por un lado, en reiteradísima jurisprudencia del Tribunal Constitucional, que una sentencia penal condenatoria supone haber destruido la presunción de inocencia y que, a su vez, tal presunción sólo se destruye si existe prueba de cargo regularmente practicada, mientras, por otro lado, están legalmente previstas y se dictan, de hecho, innumerables sentencias penales condenatorias basadas imperativamente en la conformidad del imputado con la acusación, prescindiendo de la prueba o sin que llegue a practicarse prueba alguna. He propuesto una "salida" a la situación presente, pero no es éste el lugar de extenderse en el asunto. Añadiré, en cambio, que si la incoherencia es grande en España, resulta de tamaño galáctico en los Estados Unidos de América, patria de numerosos trabajos iusfilosófico-procesales, pero donde no observo una reacción crítica proporcionada al masivo abandono de cualquier exigencia de verdad como fundamento de más del $90 \%$ de las sentencias penales condenatorias.

Del interés por la verdad en el desenlace de innumerables casos civiles tampoco puedo ocuparme aquí, pero me parece que la predicación incesante de las ADR con que desde los USA se ha bombardeado propagandísticamente al mundo jurídico europeo y latinoamericano merecería una seria reflexión desde el punto de vista de la verdad y la Justicia.
} 


\section{Defensa razonada del modelo procesal de la VIGente Ley de Enjuiciamiento Civil española en CuANto al papel del JUEZ CIVIL Y SUS PODERES EN UNA DETERMINADA SOCIEDAD}

\section{A) Exposición general}

Puesto que es notoria mi intervención en una ley procesal civil relativamente reciente y dado que, como vengo defendiendo y practicando, el papel y los poderes del juez (armónicos con los de las partes) no es asunto que deba resultar de la aplicación de axiomas o reglas dictadas por posiciones ideológicas, sino de la ponderación de diversos factores (que se han expuesto, aunque no con exhaustividad, sino sólo los más importantes y en la medida suficiente para mi argumento) de una sociedad concreta, justificar mi postura sobre el papel del juez civil y sus poderes en la sociedad pertinente (España y las sociedades con características similares), se puede identificar con la justificación del papel del juez en la Ley de Enjuiciamiento Civil No $1 / 2000$, que entró en vigor en enero de 2001. Que defienda esa concreta opción del reparto de "roles" no significa que desee exportarla (lo que se sabe muy bien en Chile). No pretendo la exportación, pero no acepto la imposición por presupuestos ideológicos y también rechazo, porque estamos hablando de asuntos jurídicos, prácticos, los modelos utópicos manifiestamente impracticables (además, claro está, de modelos que, respecto de la determinación de los hechos, condujesen a un Estado policial: aunque fuese practicable, lo rechazaría igualmente, por el mínimo ideológico expuesto supra en la nota 15).

Sentado lo anterior, procederé esquemáticamente para no alargar más estas páginas.

a) El número y tipo de jueces y el número y la índole de los litigios que afrontan no permite en absoluto diseñar un tipo de proceso civil con el enfoque (mucho más frecuente de lo que pueda parecer y de lo que quepa considerar sensato y prudente) de quien, aunque sea inconscientemente, está pensando en un solo proceso para un solo juez (e incluso para un solo abogado). El modelo procesal ha de establecerse económicamente y, más en concreto, macroeconómicamente, es decir, sobre la base de aplicar recursos limitados para resultados a escala masiva.

No se me haga sospechoso, por lo que acabo de decir, de planteamientos fundados en la productividad y en la rentabilidad de los "productos" de la Justi$\mathrm{cia}^{30}$. Sé cuánto importa la calidad del trabajo judicial y lo distancio sideralmente de la producción de tornillos. Pero la realidad de cientos de miles de asuntos

\footnotetext{
${ }^{30}$ Pocos procesalistas habrán tenido la oportunidad de vivir, como yo lo viví, siendo miembro del Consejo General del Poder Judicial, la primera propuesta de una retribución de los jueces en función
} 
civiles que esperan ser resueltos no puede eludirse. Por eso, el diseño del modelo procesal civil ha de tomar en consideración la carga de asuntos para el conjunto de los jueces, de modo que no se arroje sobre ellos un trabajo excesivo, aunque sin renunciar a que lleven a cabo en verdad el trabajo pendiente.

b) No podía ignorarse que los jueces españoles eran y siguen siendo, por mentalidad de lejanas y profundas raíces, reacios al uso de facultades o poderes que la ley les atribuía con finalidades importantes (a las que antes se ha hecho referencia). Muchos de esos jueces omitían incluso actuaciones en que la ley disponía tajantemente su presencia y actuación. Así, la práctica de pruebas como las declaraciones de testigos y de partes, que, por enorme corruptela, con frecuencia no gozaban ni siquiera de la presencia judicial. La prudencia aconsejaba un inexcusable aumento de la implicación del juez en cada proceso, pero centrándose en lo que resultaba absolutamente necesario: resolver con conocimiento de causa sobre la admisibilidad de las pruebas propuestas por las partes (llevábamos al menos un siglo en que los jueces admitían todas, aunque fuesen manifiestamente inútiles e impertinentes) y presenciar e intervenir de verdad en la práctica de pruebas, garantizando la posible contradicción y facilitando la intervención del juzgador en el interrogatorio de testigos, partes y peritos. Con esa finalidad, lograda plenamente, se diseñó el nuevo proceso civil de la Ley $N^{\circ} 1 / 2000$, que ha supuesto, sin duda, una mayor intervención del juez, un juez que ya no es espectador pasivo.

c) En un "país de abogados", con unos procesos civiles en que, desde hace siglos, la intervención de abogados es preceptiva como regla con pocas excepciones, era prudente tomar en consideración esa realidad y hubiese sido muy imprudente, por el contrario, diseñar un proceso civil de espaldas a los abogados. Lo que cabía procurar es que esa intervención fuese más real y efectiva en cada proceso, exigiendo un "plus" de dedicación al abogado pero, a la vez, una mayor oportunidad de legitimar su trabajo profesional y de ver con más claridad la relación entre ese trabajo y los resultados del proceso. En otras pocas palabras: el abogado debía verse compelido por la estructura del proceso y sus disposiciones legales a tomarse más en serio la Abogacía y a tomarse más en serio el proceso mismo.

Para la LEC 2000 se tuvo en cuenta, sí, la hipótesis teórica de desgravar a los litigantes de una buena parte de su tradicional carga de alegación, permitiendo, tras una exposición de los hechos del caso, formular sólo la pretensión de tutela jurisdiccional, sin una precisa fundamentación jurídica o, al menos, con una fundamentación meramente orientativa, de modo que, a la vez, el juez

de su productividad. Me enorgullezco de haberme opuesto tan fuertemente a ese planteamiento que no se volvió sobre él mientras ocupé aquel cargo. 
tuviese el poder de resolver conforme a las normas que estimase pertinentes, según cierta interpretación radical del iura novit curia ${ }^{31}$ o del brocardo latino da mihi factum dabo tibi ius.

Pero esa hipótesis carecía de suficiente peso real en la determinación del papel de las partes y del juez, tras dos siglos seguidos de normas procesales según las cuales correspondía a los litigantes fundamentar de modo concreto y preciso, en su aspecto jurídico, su demanda y su defensa (o eventualmente, una reconvención). Ni la Judicatura ni la Abogacía demandaban una ruptura con ese planteamiento, que, obviamente, facilitaba el trabajo decisorio del juez y al que los protagonistas del proceso estaban acostumbrados. Una constante jurisprudencia del Tribunal Supremo, e incluso del Tribunal Constitucional (en razón del respeto al derecho de defensa), avalaba el papel de las partes asesoradas por sus abogados y respaldaba la necesaria congruencia de la sentencia con el elemento jurídico de la causa de pedir.

d) La opción por hacer protagonistas absolutos de la iniciativa probatoria a las partes (salvo en los procesos civiles en que esté presente un intenso interés público) deriva de la valoración prudencial de diversos factores, ya expuestos. Pero considero conveniente reiterar, de entre ellos, la escasa inclinación -invariable durante siglos- de los mismos jueces civiles a hacer uso de poderes y facultades que se les atribuyan para un uso discrecional (que no arbitrario) y me parece necesario añadir la muy mala experiencia respecto de las llamadas "diligencias para mejor proveer", previstas en la anterior LEC, de 1881, como actuaciones probatorias que los jueces podían acordar, inmediatamente antes de dictar sentencia, con suspensión del plazo para dictarla ${ }^{32}$.

Las "diligencias para mejor proveer" no sólo eran frecuentemente utilizadas con el único fin de ampliar de facto ese plazo (en la jerga forense se les llamaba "diligencias para mejor dilatar"), sino que su práctica no respondía a criterios

\footnotetext{
${ }^{31}$ Que no es la de la LEC 2000. Su art. 218.1, pfo. primero, objetivando numerosa jurisprudencia anterior, dispone que "el tribunal, sin apartarse de la causa de pedir acudiendo a fundamentos de hecho o de Derecho distintos de los que las partes hayan querido hacer valer, resolverá conforme a las normas aplicables al caso, aunque no hayan sido acertadamente citadas o alegadas por los litigantes". Es decir, iura novit curia no significa ya absoluta libertad del juez para resolver, al margen del planteamiento jurídico de las partes, sino capacidad del juez para enmendar errores de cita, de expresión o de argumentación, siempre que se respete lo que se entiende que la parte ha querido decir.

${ }^{32}$ Nunca he recurrido a la necesaria imparcialidad del juez como fundamento de negarle iniciativa probatoria en los procesos civiles. He mencionado una sola vez la imparcialidad, con error que ahora rectifico, pues realmente quería referirme a la necesidad de respetar la igualdad de las partes, pero he pensado y pienso que la imparcialidad -la que puede ser relevante, que no es una actitud subjetiva, sino un estado o posición objetiva, sin indicios de parcialidad que deban conducir a la abstención o a la recusación- no tiene nada que ver con los mayores o menores poderes del juez, también respecto de la prueba.
} 
objetivos (ni siquiera al de llevar a cabo las pruebas propuestas y admitidas pero que no se habían practicado en el plazo legal). Así, aunque algún procesalista español, eminente pero exclusivamente teórico, se mostrase a mediados del siglo XX entusiasmado por este medio de superar las que él consideraba limitaciones del principio dispositivo o del de "aportación de parte" en obsequio de la verdad y aunque recientemente TARUFFO se haya mostrado rotundamente contrario a su supresión ${ }^{33}$, en la realidad esas pruebas acordadas ex officio por

\footnotetext{
${ }^{33}$ En la entrevista citada supra, TARUFFO se encuentra con la siguiente pregunta: "¿Qué valoración le merece que la Ley de Enjuiciamiento Civil española del año 2000 haya reducido los poderes de oficio del juez y haya eliminado las diligencias para mejor proveer?". A lo que responde así: "Merece una valoración negativa. Es difícil valorar otros sistemas, pero como observador desde fuera, en España, la ideología del proceso civil es de tipo conservador, porque no tiene en cuenta las diligencias para mejor proveer y porque mira al pasado, es decir, a los sistemas europeos de la mitad del siglo XIX en los que predominaba la figura del juez pasivo y la lucha libre de las partes. Las diligencias finales que están en la ley, a mi entender, no son diligencias para mejor proveer, porque sólo pueden determinar la renovación de las pruebas y no la práctica de pruebas nuevas. Creo que el sistema de la anterior ley de enjuiciamiento civil estaba mejor resuelto, sobre todo porque las diligencias eran posibles después de la presentación de todas las pruebas de las partes. El juez tenía la situación perfecta para establecer si necesitaba algo más para las pruebas de los hechos. El sistema anterior, a pesar de tratarse de un código liberal clásico, era perfectamente inteligente y racional".

Se comprenderá que me haya sentido algo incómodo y bastante sorprendido al leer esta frase de TARUFFO. No me encuentro cómodo con una caracterización, aunque sea indirecta, como conservador y decimonónico. Pero eso es lo de menos. Mucho más importantes son los motivos para la sorpresa. La renovada visión primordialmente ideológica, con que TARUFFO enjuicia el conjunto del proceso civil español, utilizando incluso tópicos vulgares ("de tipo conservador") ("mira al pasado, a los sistemas europeos del siglo XIX...") ("...a pesar de tratarse de un código liberal clásico..."), me sorprende y me apena, porque parece haber olvidado la información sobre la realidad española de que ha dispuesto sobreabundantemente. Mi querido colega y amigo se contradice a sí mismo porque en la misma entrevista se leen estas atinadas elementalidades: "No se puede llegar a comprender y valorar un sistema procesal sin tener en cuenta el desarrollo histórico de este sistema porque, sin la historia, no se dan términos de comparación". A lo que inmediatamente añade: "Si uno no se ocupa de lo que ocurre en Inglaterra, se pierde una parte importante de Europa. Si uno desconoce lo que ocurre en Estados Unidos, se pierde una parte importante del mundo. Y lo mismo ocurre con América Latina y la China" (la cursiva es mía). Pero si uno no se ocupa o se olvida de lo que ocurría y ocurre en España también falla en su valoración. Ese "sistema de la anterior ley de enjuiciamiento civil", que, a decir, de TARUfFo, "estaba mejor resuelto" conducía a las siguientes realidades: $1^{\text {a }}$ ) El juez resolvía sobre la admisión o inadmisión de pruebas sin conocer mínimamente el caso y, por tanto, sin disponer de parámetro alguno para decidir si las pruebas propuestas eran pertinentes y útiles. Así, el resultado era admitir todas las pruebas que se le proponían, puesto que, en caso de admitirlas, su resolución era legalmente irrecurrible; $2^{\mathrm{a}}$ ) Las distintas pruebas se practicaban (las que se practicaban) separadamente: en días distintos, aunque versasen sobre el mismo hecho; $3^{\text {a }}$ ) El juez prescindía en innumerables ocasiones del imperativo legal de presenciar la práctica de las pruebas: era sustituido por un funcionario y, por tanto, el Juez no intervenía en las pruebas; $4^{\mathrm{a}}$ ) Por haber sobrepasado el plazo legal (período de prueba), se dejaban de practicar, aun irregularmente, no pocas pruebas. El resultado era un juicio sobre los hechos presidido, de facto, por la valoración, bastante caprichosa, de la prueba documental, más un factor de pura aleatoriedad. No lo digo ahora, sino que lo dejé escrito hace tres décadas (v. supra, nota 22) $y$, por tanto, in tempore non suspecto. Esas cuatro penosas realidades han sido eliminadas por la LEC 2000, que, siempre según TARUfFo, "mira al pasado". Pues sí, se miró al pasado, pero para superarlo,
} 
el juez civil no cumplían en absoluto la alta misión de procurar la verdad, sino la de embarullar in extremis el thema decidendi y desequilibrar caprichosamente la contienda procesal. No eran acordadas siempre que podía resultar necesario en razón de la búsqueda de la verdad (más exacto sería decir que casi nunca eran acordadas con esa finalidad), no eran acordadas tampoco ni siquiera en los muy frecuentes casos límite en que no se habían practicado dentro del período de prueba (hoy desaparecido) todas las pruebas propuestas y admitidas, sino cuando al juez (o a quien por él decidiese, de facto) le convenía dilatar el plazo para dictar sentencia y, en todo caso, las más de las veces de forma errática. La prudencia aconsejaba imperiosamente, a mi parecer, suprimir lo que en modo alguno cumplía su papel teórico y sí resultaba profundamente perturbador, propicio a vulneraciones del principio de igualdad de las partes. Por tanto, se procuró de otros modos (que a menudo son silenciados) implicar mucho más al juez en la labor de buscar la verdad ${ }^{34}$.

e) Por otra parte, dos factores más fueron prudencialmente considerados de modo especial. Primero, la razonable seguridad de que sólo los jueces con inclinación al protagonismo personal (los que en España denominamos "jueces estrella") harían uso con relativa frecuencia de unos eventuales poderes de iniciativa probatoria y, muy probablemente, sólo en casos "mediáticamente" importantes. Segundo, que, para la generalidad de los jueces españoles, la res-

para dejarlo atrás. Porque lo que he expuesto son hechos, verdades, que TARUFFo no debería negar ni silenciar o despreciar. La LEC 2000 se preocupa eficazmente de la prueba y propicia la intervención del juez en la prueba, siempre en interés de la verdad, incomparablemente más que la LEC de 1881.

${ }^{34}$ Nadie ha pretendido que las "diligencias finales" sean las "diligencias para mejor proveer". Por el contrario, el esfuerzo justificativo de la LEC 2000 se ha centrado en todo lo contrario: en que no se viesen las "diligencias finales" como unas renovadas "diligencias para mejor proveer". Éstas son sustituidas por unas diligencias distintas ("con presupuestos distintos de los de aquellas", dice literalmente la Exposición de Motivos), que no sólo permiten la renovación de pruebas (con una clara finalidad de efectividad en el hallazgo de la verdad, que TARUFFo silencia), sino la realización de pruebas admitidas y no practicadas, lo que no se lograba casi nunca con las "diligencias para mejor proveer" ni con el conjunto del sistema de la LEC 1881, que "estaba mejor resuelto".

Desde hace mucho tiempo (más precisamente desde 1974, en el segundo ejercicio de mi concurso público de acceso a Cátedra, publicado después: "Sobre conceptos básicos del Derecho Procesal", en Revista de Derecho Procesal Iberoamericana, núm. I, 1976, pp. 212-214) tengo la convicción de que para el procesalista es vital y primario ocuparse de la Justicia posible (dicho de otra forma: intentar, aunque no le dejen, mejorar la Justicia que, aquí y allá, se imparte mediante procesos). Para esa tarea, la realidad del factor humano, con sus raíces históricas o culturales hondas y también con episodios convulsivos de efectos importantes, ha de ser objeto de pesquisa y de muy atenta valoración, tanto, al menos, como las teorías y doctrinas.

Aquí he venido sosteniendo que el sistema procesal debía diseñarse a base de juicios prudenciales para lograr un resultado viable y mejor. Excepcionalmente, casi milagrosamente, el debate parlamentario que en España condujo a aprobar la LEC 2000 se orientó con sentido práctico y prudencial, lo que explica que la LEC fuese aprobada con los votos favorables de posiciones políticas muy opuestas, como el Partido Popular e Izquierda Unida. 
ponsabilidad aneja al poder de decretar pruebas de oficio resultaría una carga imposible de llevar.

Tal vez algunos encuentren apasionante como ejercicio intelectual (e incluso moral) imaginar un proceso civil con las características teóricamente ideales y, sobre todo, diseñar el papel del juez del mismo modo, pensando en un juez que, empeñado en la verdad y en la justicia y siempre atento a cada uno de sus asuntos, interviene a cada paso en que considera que su actuación servirá a esos nobilísimos fines. Podemos describir con bellas palabras el ideal de que la máquina estatal de la Justicia no escatime esfuerzos respecto de cualquier situación, por común que sea, en que un ciudadano necesite tutela porque puede estar padeciendo lesión de sus derechos o, dicho de otra forma, puede ser víctima de un comportamiento ilícito. De hecho, no son pocos quienes, sin advertirlo, vienen a propugnar, para el proceso civil, un juez máximamente protector $y$, en consecuencia, dotado de amplios poderes, entre los cuales los probatorios; quisieran un juez como el que, antaño (no ahora, ya lo sabemos y lo hemos apuntado), debía ocuparse de los ilícitos más graves, los penales.

Sin embargo, en sociedades como la española y otras similares, hay que entender que, a la hora de proyectar modelos procesales, no es ni razonable ni asequible (más bien, resultaría imposible) que sea principalmente el Estado, a través de los tribunales, quien haya de ocuparse -con la correlativa responsabilidad de los servidores públicos- de comprobar la certeza de los hechos -rectius: de las afirmaciones de hechos- que configuran la inmensa mayoría de los casos llevados ante los órganos jurisdiccionales civiles. Si bien se mira, todos los demandantes, promotores de los procesos civiles, exponen al tribunal lo que consideran que es un comportamiento ilícito. Pero si, en todo el mundo, la Administración de Justicia a duras penas puede, con los auxilios de los demás poderes del Estado, afrontar los más graves y reprochables "ilícitos" -los constitutivos de delitos perseguibles de oficio-, constituiría un empeño estrictamente utópico gravar a los tribunales con la responsabilidad primordial en la comprobación de los hechos de todas las pretendidas conductas ilícitas, también de aquéllas que no afectan al interés general, sino sólo a los derechos e intereses de determinadas personas o sujetos jurídicos ${ }^{35}$.

\footnotetext{
35 “Enteramente utópica -y estremecedora, para personas experimentadas- sería la visión de un aparato estatal o público encargado, no ya de comprobar lo que los ciudadanos y los sujetos jurídicos adujesen como actos ilícitos de toda clase, sino de investigar todo género de ilicitudes, también las civiles y mercantiles, para aplicar el Derecho en todos los casos. Idealmente, podría pensarse en la perfección. Pero históricamente... Quizá estas utopías debieran hacer meditar a quienes, probablemente con buena intención, quisieran atribuir a órganos públicos -a la postre, integrados por personas de igual condición que las demás- todos los aspectos de lo que se denomina 'hacer justicia'". V. mi Derecho Procesal Civil, con Díez-Picazo Giménez, cit., §37, núm. 2.
} 
Lo que hoy -y por mucho tiempo- resulta prácticamente imposible, sería, además, muy poco razonable. Una muy amplia y prolongada experiencia casi universal (aún más clara en los "países de abogados", a que antes nos referimos) enseña que, en el tráfico jurídico, de los negocios y situaciones de las que se derivan derechos e intereses legítimos se suele dejar constancia por los sujetos interesados, no sólo a los efectos de posibles procesos, sino incluso a los fines de la protección y satisfacción de esos derechos e intereses y del cumplimiento espontáneo o inducido de deberes jurídicos. Por tanto, esos sujetos se encuentran, de ordinario, en mejores condiciones que nadie para aportar las pruebas y lograr, conforme a reglas racionales, un resultado de certeza sobre los hechos relevantes para la decisión judicial que procesalmente se requiera en cada caso. Por todo ello, un modelo procesal civil prudente y razonable no se basa en la investigación ex officio de los hechos que se afirman relevantes y no atribuye a los tribunales la responsabilidad -a todas luces excesiva- de procurar establecer la certeza positiva o negativa, sino que, sobre una base lógica y conforme a la experiencia, resulta preferible disponer que sean las partes de cada proceso los principales protagonistas de la iniciativa y del esfuerzo conducentes a aquella certeza.

Quizá, pese a lo anterior, y aun admitiendo que, de ordinario, corresponda a las partes un papel predominante en la prueba, se insista en dotar al juez civil de un poder de acordar pruebas de oficio excepcionalmente. Pero, además de que resulta difícil establecer los casos excepcionales, esa potestad encierra el peligro de que el juez, al usarla, en un "proceso de abogados", lesione el principio de igualdad de las partes. Si el demandado es descuidado, ipor qué tiene el tribunal que cuidarse de remediar su descuido? Si lo hace, le estará favoreciendo, en perjuicio del demandante, quizá cuidadoso y diligente. Y si remedia la insuficiencia de la actividad probatoria del demandante, perjudicará indefectiblemente al demandado.

A todo eso cabe oponer que "el interés de la verdad" está por encima de cualquier otro valor. Esta proposición me parece cierta en sí misma. Porque, valor por valor, yo pongo personalmente la verdad por delante incluso de la justicia. Pero no veo el sentido y la pertinencia de una comparación entre valores cuando hablamos del modelo o sistema procesal, porque, a propósito del modelo o sistema, ya se debe haber elegido aquél que prudencialmente pueda perseguir -no en teoría, sino en la realidad y de modo de ordinario satisfactoriolos distintos valores que importan. Y sabemos que la verdad no es el único. Si se desconfía de las partes y de los abogados profundamente y, en cambio, se confía en los jueces al máximo, el modelo de proceso bien podría prescindir de la estructura contradictoria con iguales oportunidades de las partes. Si alguien me muestra una sociedad en que verdaderamente los jueces merezcan la máxima confianza y, en cambio, los litigantes y sus asesores jurídicos no merezcan 
apenas confianza, no formularía yo ninguna objeción a un diseño de proceso civil que atribuyese grandes poderes y responsabilidades al juez, en todos los aspectos que ya se expusieron. Pero, eso sí, estaríamos hablando de un tipo de proceso inquisitivo o casi y, personalmente, me apenaría una sociedad en la que existiese una notable desigualdad entre los profesionales del Derecho: los jueces serían trabajadores y sabios; los abogados, por el contrario, perezosos e ignorantes.

Ahora bien, cuando se ha optado por un proceso con estructura dialógica y partes (asesoradas por abogados) con iguales oportunidades de defender cada una su posición (y ésta me parece que es la opción generalmente preferida en los países que son considerados civilizados: la opción no tiene nada de typical spanish), las paredes maestras de esa construcción no pueden ser alteradas, porque, aunque la construcción misma implica riesgos para las partes (y sus abogados) que no extremen su diligencia y cometan errores, peor es el peligro de arrojar sobre los jueces responsabilidades excesivas y el riesgo de que, objetivamente, lesionen la igualdad entre las partes. Éste es un punto crucial: o, aun con abogados preceptivos, se arroja sobre los jueces la responsabilidad de rectificar los errores de los litigantes, lo que no me parece coherente con un modelo procesal civil contradictorio e igualitario, o, por el contrario, ha de darse por sentado, con normalidad, que, en ocasiones, "el interés de la verdad" e incluso el de la justicia no serán bien servidos e incluso serán a veces defraudados, con resultados negativos para un litigante. Ésta es, a mi entender, la opción preferible, porque, insisto, me parece imprudente echar sobre las espaldas de los jueces civiles la carga y la responsabilidad de enmendar lo que las partes no hagan o hagan mal. Y también porque el uso por los jueces de potestades de iniciativa probatoria tampoco eliminaría necesariamente posibles errores e injusticias, dado que el juez es tan humano como el abogado ${ }^{36}$.

\footnotetext{
${ }^{36} \mathrm{Me}$ permito reiterar que no defiendo la pretendida pureza de un principio doctrinario -para empezar, porque no es "doctrinario" el principio dispositivo, ni su corolario, el de aportación de parte-: lo que defiendo es el debate entre las partes, porque ni siquiera en un proceso penal, en el que se ventila un claro interés público, resulta razonable que el tribunal indique a la acusación o a la defensa lo que podrían proponer como pruebas conducentes. Lo que resulta razonable en el proceso penal es que el tribunal pueda ordenar la práctica de pruebas pertinentes y así lo disponía la LECrim. Un lamentable entendimiento del denominado "principio acusatorio" ha conducido a sostener que el tribunal del proceso penal no puede decretar, sin instancia de parte, la práctica de pruebas. Si se configura el proceso penal como el civil, ¿acaso no se entiende que, en el proceso civil como en el penal, el interés de una parte por el "esclarecimiento de los hechos controvertidos" es opuesto al interés de la parte contraria y que el tribunal no tiene por qué favorecer un interés sobre otro? Pero en el proceso civil, insistimos, son de ordinario los derechos de Ticio, Cayo y Sempronio los que se ventilan. Si se rechaza que Ticio, Cayo y Sempronio, obligatoriamente asesorados y representados por profesionales expertos, asuman plenamente la carga de hacer todo lo que les conviene, ipor qué no facultar al tribunal para aleccionar a las partes sobre la suficiencia o insuficiencia de los fundamentos jurídicos? Pero, si se atribuye a los tribunales esas facultades - que también son, no se olvide, responsabilidades- ¿para qué
} 
f) En conclusión: salvo que el proceso civil tenga por objeto casos en que esté implicado un interés general o público, es prudente y razonable que sean los sujetos jurídicos interesados los protagonistas del esfuerzo de alegaciones y prueba, puesto que son bienes jurídicos suyos los que están en tela de juicio y puesto que resulta utópico y poco prudente -por no decir insensato- gravar a los tribunales de justicia con una carga superior a la de dirigir bien el proceso, presenciar y valorar las pruebas y dictar sentencia bien motivada y justa.

Aunque no considere intrínsecamente perverso, en abstracto, un modelo procesal civil en que se atribuya al juez un papel superprotagonista, que incluya ocuparse de los fundamentos jurídicos y de los hechos, es fácil estar en condiciones de comprender que eso supone echar sobre los hombros del juez una tarea ímproba y de la que no puede hacérsele responsable, como ya se explicó antes. Considero más lógico y conforme a la naturaleza de las cosas que, supuestos los abogados, quien pide para sí una tutela jurídica a los órganos jurisdiccionales exponga lo que, a su juicio, fundamenta -tanto fáctica como jurídicamente- la petición formulada. Ante todo, porque ese sujeto jurídico conocerá, de ordinario, unos hechos que los tribunales casi siempre desconocerán; en segundo lugar, porque, como ya dije, también entra en la esfera del poder de disposición de los sujetos jurídicos hacer o no uso de cuanto sustenta y apoya fáctica y jurídicamente los derechos que esos sujetos afirman tener y en virtud de los cuales formulan sus pretensiones de tutela jurídica (no de terminación de una controversia); en tercer lugar, porque cabe suponer racionalmente que la máxima diligencia en alegar hechos y argumentos y en aportar pruebas será desplegada por quienes pretenden una sentencia favorable para ellos ${ }^{37}$.

los abogados? Y, si se asumen por los tribunales esos "roles", ipodrán cumplirlos, respecto de todos los sujetos jurídicos? Mi respuesta es que, en España, desde luego, no pueden cumplirlos: no han podido ni querido cumplirlos cuando eran menores que en la actualidad y ahora no hay nada que sostenga una tendencia opuesta.

${ }^{37}$ Puedo hacer míos, en consecuencia, los siguientes párrafos de la Exposición de Motivos de la LEC:

"La nueva Ley de Enjuiciamiento Civil sigue inspirándose en el principio de justicia rogada o principio dispositivo, del que se extraen todas sus razonables consecuencias, con la vista puesta, no sólo en que, como regla, los procesos civiles persiguen la tutela de derechos e intereses legítimos de determinados sujetos jurídicos, a los que corresponde la iniciativa procesal y la configuración del objeto del proceso, sino en que las cargas procesales atribuidas a estos sujetos y su lógica diligencia para obtener la tutela judicial que piden, pueden y deben configurar razonablemente el trabajo del órgano jurisdiccional, en beneficio de todos".

"De ordinario, el proceso civil responde a la iniciativa de quien considera necesaria una tutela judicial en función de sus derechos e intereses legítimos. Según el principio procesal citado, no se entiende razonable que al órgano jurisdiccional le incumba investigar y comprobar la veracidad de los hechos alegados como configuradores de un caso que pretendidamente requiere una respuesta de tutela conforme a Derecho. Tampoco se grava al tribunal con el deber y la responsabilidad de decidir qué tutela, de entre todas las posibles, puede ser la que corresponde al caso. Es a quien cree necesitar tutela a quien se atribuyen las cargas de pedirla, determinarla con suficiente precisión, alegar y probar 
B) A modo de "test" sobre eficacia y responsabilidad:

Una norma de la LEC española que aumenta el protagonismo del juez

El art. 429.1, párrafo segundo LEC establece una posible iniciativa del tribunal, respecto de la proposición de prueba en el juicio ordinario y, en concreto, en la audiencia previa. Según ese precepto, si el tribunal considera que las pruebas propuestas por las partes pueden "resultar insuficientes para el esclarecimiento de los hechos controvertidos, lo pondrá de manifiesto a las partes indicando el hecho o hechos que podrían verse afectados por la insuficiencia probatoria". Y prosigue: "al efectuar esta manifestación, el tribunal, ciñéndose a los elementos probatorios cuya existencia resulte de los autos, podrá señalar también la prueba o pruebas cuya práctica considere conveniente".

Como quiera que el último párrafo del art. 429.1 LEC prevé que, en tal caso, "las partes podrán completar o modificar sus proposiciones de prueba a la vista de lo manifestado por el tribunal", es indiscutible (aunque unos pocos pero queridos colegas han llegado a discutirlo y afirmar lo contrario) que no le corresponde al tribunal acordar u ordenar la práctica de pruebas, sino señalar las que consideraría convenientes. A las partes incumbe proponerlas, o no, completando o modificando, en su caso, sus anteriores propuestas.

He de reconocer que he suavizado mi inicial criterio sobre este precepto, que no aparecía en el Proyecto de LEC (aunque conocí la enmienda transaccional y no la consideré inaceptable). Con todo, sigo pensando -y lo piensan muchos otros- que este bienintencionado mecanismo es de utilización nada fácil y que, además, puede resultar inconveniente. No es fácil que, por mucho que la nueva estructura del juicio ordinario comporte, como era deseable, un conocimiento mayor del caso por el tribunal, éste se encuentre en condiciones de señalar pruebas pertinentes, indicando el hecho o hechos que, a su juicio, podrían verse afectados por la insuficiencia probatoria. Y si advertimos que esa indicación de pruebas ha de hacerla el tribunal "ciñéndose a los elementos probatorios cuya existencia resulte de los autos", aún resulta menos fácil la

los hechos y aducir los fundamentos jurídicos correspondientes a las pretensiones de aquella tutela. Justamente para afrontar esas cargas sin indefensión y con las debidas garantías, se impone a las partes, excepto en casos de singular simplicidad, estar asistidas de Abogado".

"Esta inspiración fundamental del proceso -excepto en los casos en que predomina un interés público que exige satisfacción- no constituye, en absoluto, un obstáculo para que (...) el tribunal aplique el Derecho que conoce dentro de los límites marcados por la faceta jurídica de la causa de pedir. Y menos aún constituye el repetido principio ningún inconveniente para que la Ley refuerce notablemente las facultades coercitivas de los tribunales respecto del cumplimiento de sus resoluciones o para sancionar comportamientos procesales manifiestamente contrarios al logro de una tutela efectiva. Se trata, por el contrario, de disposiciones armónicas con el papel que se confía a las partes, a las que resulta exigible asumir con seriedad las cargas y responsabilidades inherentes al proceso, sin perjudicar a los demás sujetos de éste y al funcionamiento de la Administración de Justicia". 
utilización de la facultad legal. Porque en ese momento procesal (la audiencia previa al juicio), los elementos probatorios -cuya "existencia" no resultará de los autos, sino que constará en ellos- no pueden ser otros que los elementos escritos (documentos, dictámenes, informes) o instrumentos similares y, excepcionalmente, los resultados de la prueba anticipada, si se acordó en su momento. No parece razonable que el tribunal, en tal momento, haya de realizar una valoración de esos elementos, ni siquiera provisional. Y pronunciarse, aunque sea provisionalmente, sobre insuficiencia probatoria, exige un prejuicio, que no se entiende cómo puede formarse.

Pero lo que aquí interesa no es un estudio detenido del precepto ${ }^{38}$, sino la experiencia de su existencia y aplicación. Al respecto puedo afirmar que los jueces vienen haciendo muy poco uso de los poderes que les atribuye esa norma. Pero, en cambio, a la vista de la doctrina y de la denominada "jurisprudencia menor" (la que constituyen las sentencias no emanadas del Tribunal Supremo), resulta claro que la norma ha suscitado interrogantes problemáticos que seguramente no estaban previstos.

Ocurre, en efecto, que el art. 429.1 LEC prevé dos posibles conductas del juez: la primera, indicar a las partes la posible insuficiencia de las pruebas propuestas con indicación de los hechos a los que dicha insuficiencia afectaría; la segunda, sugerir a las partes pruebas que les podría convenir proponer. Para la primera conducta, la ley utiliza una expresión literalmente imperativa: "lo pondrá de manifiesto (AOS: la insuficiencia probatoria)". Para la segunda, la norma usa términos de apariencia no imperativa: "podrá señalar" (la prueba o pruebas). Sobre la base de esta diferencia literaria, a mi juicio escasamente relevante, se sostuvo inicialmente que el juez civil tenía el deber de vigilar la presumible suficiencia de las pruebas propuestas por las partes, de modo que, en caso de no cumplir tal deber, si se dictaba una sentencia fundada en la falta de prueba (en el sentido de no haberse propuesto), el incumplimiento del deber originaría la nulidad de las actuaciones ${ }^{39}$.

\footnotetext{
${ }^{38}$ Me parece prudente y bien razonado, por ejemplo, el trabajo de Fernández López, Mercedes, "Las facultades probatorias del juez civil previstas en el art. 429.1, II LEC", publicado en la revista jurídica Práctica de Tribunales. Revista de Derecho Procesal Civil y Mercantil, núm. 21, noviembre 2005. En cambio, no puedo aceptar la "interpretación" del art. 429.1, II propuesta por Picó I JunOr en loc. cit. supra, nota 19 in fine. Él mismo reconoce que su propuesta va más allá de la interpretación jurídica de la norma. Estoy tan firmemente convencido de la excelente intención de Pıcó (acomodarse al "Estado Social y Democrático de Derecho") como del error que entraña desbordar el texto, el contexto y el sentido y finalidad de un precepto legal no irracional para conseguir el resultado acorde con la personal preferencia, por más que se apoye en los más elevados principios.

${ }^{39}$ Así lo defendió inicialmente la Sentencia de la Audiencia Provincial (AP) de Ciudad Real, de 28 de mayo de 2002. En su Fdto. Jdco. Tercero, decía así: "si el Juez, constatado el supuesto de hecho del artículo comentado, no revela la insuficiencia de prueba, tal omisión puede constituir fundamento para la nulidad de actuaciones, si finalmente la sentencia desestima la pretensión o resistencia por esa falta
} 
Pero lo que ha triunfado, dejando a un lado la posición favorable a la nulidad radical de actuaciones, es que no existe deber judicial en ninguno de los dos casos, sino una facultad de ejercicio discrecional, de modo que, en último término, no podría cometerse infracción del art. 429.1 LEC ${ }^{40}$. No puedo aceptar

de prueba, pues se priva a las partes de una oportunidad procesal, ligada a la actuación que la Ley exige al Juez. Más dudoso es si la no mención de los medios probatorios, resultantes de los autos, que el Juez considere convenientes, puede constituir vicio anulatorio". Esta tesis, ya abandonada, nunca me pareció sólida: en primer lugar, porque no es fácil encajar la inactividad judicial que nos ocupa en uno de los supuestos de hecho de la nulidad y, en concreto, en el aptdo. 3 del art. 225 LEC: "cuando se prescinda de normas esenciales del procedimiento, siempre que, por esa causa, haya podido producirse indefensión". El art. 429.1 LEC no me parece una "norma esencial del procedimiento". En segundo lugar, la consecuencia de la nulidad sería absolutamente contraria a lo que se quiere: una sentencia sobre el fondo. En tercer lugar, los procesos civiles se verían masivamente afectados por posibles nulidades, lo que resultaría catastrófico para la Justicia civil en su conjunto.

${ }^{40}$ En un sentido opuesto a la precitada SAP de Ciudad Real, es la posterior SAP de Madrid (Sección $\left.11^{\mathrm{a}}\right)$, de 28 de diciembre de 2007. En su Fdto. Jdco. Tercero puede leerse lo siguiente: "Pues bien, el primer problema que ha suscitado dicho precepto innovador, como consecuencia de su ambigua dicción, consiste en si se trata de un deber o, por el contrario, de una mera facultad del órgano judicial, inclinándose la doctrina científica más autorizada y la denominada jurisprudencia menor -SAP de Murcia de 15 de febrero de 2002, SAP de Badajoz de 3 de mayo de 2002, SAP de Lugo de 29 de mayo de 2002, SAP de Pontevedra de 17 de junio de 2002, SAP de Navarra de 16 de abril de 2002, SAP de Burgos de 23 de julio de 2002, SAP de Alicante de 30 de octubre de 2002, SAP de Córdoba de 6 de febrero de 2003, entre otras-, a la vista de su interpretación conjunta, sistemática y finalista, que se trata de una facultad judicial condicionada a la subjetiva constatación sobre la insuficiencia de las pruebas ya propuestas para acreditar los hechos controvertidos, con la finalidad última de convencer al órgano jurisdiccional de la bondad de la pretensión actuada, señalando la citada doctrina jurisprudencial que se trata de una apreciación subjetiva que difícilmente podrá ser objeto de control externo y a posteriori por otro órgano judicial para imponer su propio criterio, sin que pueda servir de fundamento para subsanar la inexistencia de prueba o las propuestas por las partes inadecuadamente, así como que las actuaciones no se puede retrotraer hasta la proposición de prueba para dar posibilidad a las partes para proponer la necesaria para acreditar su derecho".

"En definitiva, la nueva norma introduce un mecanismo para facilitar la convicción judicial sobre los hechos controvertidos mediante la facultad de integración probatoria, pero no impone al juez un deber de controlar la suficiencia probatoria en la inicial fase de la audiencia previa, ni existe una garantía absoluta de que, aun con indicación de insuficiencia probatoria, las nuevas pruebas acrediten los hechos controvertidos, todo ello sin olvidar que la normativa de la carga de la prueba del artículo 217 de la LEC, que opera al tiempo de dictar sentencia, no se halla supeditada al uso de la facultad del artículo 429". La SAP de Baleares, de 9 de febrero de 2006, sostiene, también en contra de la tesis inicial expresada por la ya citada SAP de Ciudad Real, que, de interpretarse que el artículo $429 \mathrm{im}$ pone un deber, el juez debería controlar de oficio la idoneidad de los medios probatorios propuestos, como si se tratara de presupuestos procesales, lo que violaría el principio de aportación de parte. A mi parecer, entender que el art. 429.1 LEC entraña un deber del juez no convierte la idoneidad de los medios probatorios en presupuesto procesal (no se trataría de un elemento del que dependiese la regularidad del proceso mismo) y no se opone al principio de aportación de parte, puesto que al aplicar el art. 429.1 LEC un juez no ejercita una iniciativa de aportación de prueba y las partes son libres de seguir, o no, las indicaciones del juez.

Lo que se acaba de exponer puede considerarse actualizado. A título de ejemplo, véase lo que afirma la SAP de la Rioja, de 19 de mayo de 2012: "En cuanto a la referencia que se hace en el recurso de apelación en relación con el artículo 429. 1 LEC, si bien es cierto que, conforme a dicho precepto, el 
esta conclusión. De antiguo tengo escrito ${ }^{41}$ que el tenor literal de las normas en preceptos como ésta resulta poco fiable. Porque, en primer lugar, y ante todo, las normas que facultan al juez, no tienen el sentido de permitirle hacer algo según su libre arbitrio, pues la facultad se concede para cumplir una finalidad legal, sin que sea indiferente que el juez haga o no haga lo que la ley prevé cuando se encuentra ante un caso como el previsto. Si la finalidad ha de ser perseguida y el juez no lo hace, no debe encontrar una seria excusa en un "podrá". Esas normas pueden ser infringidas y, de hecho, se infringen. En segundo lugar, porque los términos no imperativos (además de a ligereza e imprecisión legislativa) pueden obedecer (aunque no estén plenamente justificados) a que la ley deja al juez la apreciación de los casos en que se podría encontrar en el trance de usar la facultad. La consecuencia es, a mi entender, que una ley que diga al juez que puede dirigir él mismo preguntas al testigo cuando sus declaraciones no le parezcan claras, etc., tiene en realidad idéntico contenido a la que, sobre el mismo supuesto, se exprese imperativamente y diga que el juez pedirá aclaraciones.

Pero mi criterio no ha sido seguido por la jurisprudencia menor, que niega la existencia de un deber judicial, lo que confirma la resistencia de los jueces españoles a asumir poderes o facultades de actuación ex officio. Ha quedado desactivada también la cuestión de la posible responsabilidad por no indicar la insuficiencia probatoria o no señalar medios de prueba o por no hacer caso (los abogados) de las indicaciones del juez, si el resultado es después perjudicial para la parte asistida por ese abogado.

Tribunal cuando considere que las pruebas propuestas por las partes pudieron resultar insuficientes para el esclarecimiento de los hechos controvertidos lo pondrá de manifiesto en las mismas, indicando el hecho o hechos que, a su juicio, podrían verse afectados por la insuficiencia probatoria, indicando incluso la clase de medios de prueba a practicar, tal posibilidad no es preceptiva sino meramente facultativa para el juzgador en dicho precepto, lo contrario sería entender que el juzgador tiene la obligación de la carga de la prueba, que corresponde a las partes de modo que se rechaza esa referencia a este precepto, ya que la actora es la que realmente tenía que acreditar los hechos de su pretensión y no pretender que sea el juzgador quien justifique los mismos Por tanto, no puede reprocharse al Juez que no hiciera uso de las facultades que le atribuye el artículo 429.1 de la Ley de Enjuiciamiento Civil o, en su caso, el artículo 372.2 de la Ley de Enjuiciamiento Civil, pues lo que pone de manifiesto el juzgador no son dudas o la falta de prueba sobre hechos relevantes para la resolución del litigio, sino la falta de diligencia probatoria de la parte demandante que no aporta prueba suficiente para justificar los hechos base de su pretensión, pues, en definitiva, no corresponde al juez suplir la inactividad probatoria de la parte demandada asumiendo su papel para acreditar su pretensión". En el mismo sentido, la SAP de A Coruña, de 26 de abril de 2012, que cita las SS.AA.PP. de Tarragona, de 20 de octubre de 2009, de Alicante, de 11 de noviembre de 2010, de Castellón, de 18 de abril de 2011 y de Asturias, de 6 de febrero de 2012.

${ }^{41}$ V. De La Oliva, "Algunas peculiaridades de las normas procesales", en Revista de Derecho Procesal Iberoamericana, II, 1974 y, condensadamente, en mi Derecho Procesal. Introducción, cit., § 6, núms. 30 a 34. 


\section{Epílogo}

Las ideologías pasan, cambian y se disfrazan una y otra vez, pues cada vez es más raro que surjan innovaciones verdaderas, merecedoras de respeto intelectual. Pero, frente a quienes proclamaron su ocaso o decretaron su fin, no veo que las ideologías merezcan una enmienda a la totalidad, por así decirlo, siempre que no se constituyan en absolutos, que no engullan los innumerables espacios de la libertad individual y social y que no pretendan, contra la evidencia histórica, eliminar cualquier interrogante abierto o responder con perfección a todas las preguntas que la realidad y el buen sentido suscitan. La prudencia, en cambio, está ahí, intacta e indiscutida, desde hace miles de años, como rectora de nuestras decisiones en innumerables aspectos de la vida personal y de la convivencia humana. Las decisiones sobre el diseño de los procesos jurisdiccionales civiles (y también, en buena medida, los no civiles) deberían adoptarse, para beneficio general, por la auriga virtutum de Platón y de Aristóteles. El terreno que la Justicia ha de recorrer mediante los procesos no es un espacio de teorías encontradas, una palestra retórica de abstracciones y utopías, sino la realidad histórica, con sus múltiples y muy diversos elementos, aquí o allá. Con un auriga prudente, la Justicia puede avanzar más y mejor. Ésa es mi tesis y aquí he querido explicarla, es decir, desplegarla (eso es, etimológicamente, explicar: ex-plicare), del modo más completo posible, poniéndola a prueba y sometiéndola de nuevo al público escrutinio. 